\author{
UNIVERSIDADE DE SÃO PAULO \\ Faculdade de Filosofia, Ciências e Letras de Ribeirão Preto \\ Departamento de Psicologia e Educação \\ Programa de Pós-Graduação em Psicobiologia
}

Comportamento de filhotes de rato (Rattus norvegicus) em um campo aberto na presença e na ausência de animais adultos

Ana Carolina Guilhermitti 

Ana Carolina Guilhermitti

\title{
Comportamento de filhotes de rato (Rattus norvegicus) em um campo aberto na presença e na ausência de animais adultos
}

\begin{abstract}
Dissertação apresentada à Faculdade de Filosofia Ciências e Letras de Ribeirão Preto, da Universidade de São Paulo, como parte das exigências para a obtenção do título de Mestre em Ciências, área de Psicobiologia.
\end{abstract}

Orientador: Prof. Silvio Morato 
AUTORIZO A REPRODUÇÃO E DIVULGAÇÃO TOTAL OU PARCIAL DESTE TRABALHO, POR QUALQUER MEIO CONVENCIONAL OU ELETRÔNICO, PARA FINS DE ESTUDO E PESQUISA, DESDE QUE CITADA A FONTE.

\section{FICHA CATALOGRÁFICA}

Guilhermitti, Ana Carolina

Comportamento de filhotes de rato (Rattus norvegicus) em um campo aberto na presença e na ausência de animais adultos. - Ribeirão Preto, 2011.

46 p.; 8 il. ; $30 \mathrm{~cm}$.

Dissertação de Mestrado, apresentada à Faculdade de Filosofia, Ciências e Letras de Ribeirão Preto/USP - Área de concentração: Psicobiologia.

Orientador: Morato, Silvio.

1. Comportamento exploratório. 2. Ansiedade. 3. Campo aberto. 4. Filhotes. 5. Apego a adultos. 


\section{Agradecimentos}

Ao professor Silvio Morato, pelas orientações para a realização deste trabalho e pela amizade, muito obrigada!!!

À Professora Claudia Padovan, pelas importantes sugestões e pelo tempo dedicado às correções destes trabalho, meus sinceros agradecimentos!

Aos meus pais, Marilene e Mário por serem minha referência e que, mesmo sem entender muito para que serviam os ratos, estiveram sempre presentes com seus conselhos e seu carinho! Amo vocês!!!!

Às minhas irmãs, Camila e Débora, e ao meu cunhado Junior, por fazerem parte da minha vida!

Ao Paulo, em especial, que desde o dia da inscrição para o mestrado esteve presente, passando pelas limpezas de animais em datas comemorativas e me buscando quando eu já tinha perdido o ônibus para Batatais. Acredito que não seria possível esta realização sem você. Obrigada pelos conselhos, pela paciência, pelo seu bom senso em resolver problemas, pelo seu bom humor, enfim, por você fazer parte da minha vida!!! Por todo carinho, compreensão e apoio dedico a você parte do sucesso desta etapa!!!

À minha segunda mãe Marta, meu porto seguro nos momentos difíceis, por não me deixar desistir, por acreditar e me fazer acreditar que é possível sempre!!! Você tem um lugar especial no meu coração!!!

Às minhas super amigas, Yara Fabrine, Carlinha, Jeanny, Danila, Natália, em especial a Jú e a Renata Brain, companheiras de conversas, de conselhos, desde os estudos para as provas até o final deste ciclo. À todas vocês meu carinho especial por toda a vida!!! 
Aos meus amigos, Édson, Dudu, Roberto, Eduardo, Diego, Lucas e o Ricardo, pela amizade, pelas risadas, pelos momentos de cantina, pelas conversas jogado fora e pelas discussões que fizeram diferença! Adoro vocês!!!

Aos meus mais que amigos de laboratório: Milena, Javier, Julian e Thiago, por toda a paciência que não foi pouca, pelas horas extras dedicadas às minhas dúvidas, pelo tempo perdido na cantina e pelos cafés com bobagem. Não teria sido possível a realização deste trabalho sem vocês! Vocês se tornaram muito especiais!!! Obrigada!!!

À Renata Vicentini, que com seu exemplo de mulher determinada e organizada faz além do seu trabalho, se dispondo a ajudar com seus conselhos, ouvindo e se tornando muito especial. Muito obrigada por tudo Rê!!!

Ao Paulinho pela amizade, pelas conversas e pelos churrascos!!!

Ao pessoal do biotério pelo trabalho feito com carinho e atenção.

Ao pessoal da cantina e demais funcionários no qual sempre mantive um bom convívio.

Ao Diretor e coordenadores da Escola Geraldo Tristão de Lima pelo apoio e compreensão.

Aos meus amigos da Faculdades Claretianas, Pricila Bertanha, Priscila Engel e Silvia, que numa fase de transição, me orientaram na escolha certa. Meu muito obrigada pela amizade!!!

Aos pequenos filhotes de ratos, que em meio às pinturas de pelo e exposições à arena tornaram possível este trabalho.

Ao CNPq, pelo apoio financeiro que possibilitou a realização do meu trabalho. 


\section{LISTA DE FIGURAS}

Figura 1. Campo aberto com gaiola de pássaros anexada em uma das paredes

Figura 2. Representação esquemática do campo aberto

Figura 3. Médias das frequências de entradas nos cantos do campo aberto $( \pm$ EPM) dos filhotes testados em grupo e individualmente no campo aberto, na presença e ausência do animal adulto

Figura 4. Médias do tempo gasto nos cantos do campo aberto ( \pm EPM) pelos filhotes testados na presença e ausência do animal adulto

Figura 5. Médias das frequências de entradas nas áreas de uma parede do campo aberto $( \pm$ EPM) pelos filhotes testados em grupo e individualmente, na presença e ausência do animal adulto

Figura 6. Médias do tempo gasto nas áreas de uma parede do campo aberto ( \pm EPM) por filhotes testados em grupo e individualmente, na presença e ausência do animal adulto

Figura 7. Médias das frequências de entradas no quadrado em frente da gaiola ( \pm EPM) pelos filhotes testados em grupo e individualmente, na presença e ausência do animal adulto

Figura 8. Médias do tempo gasto no quadrado em frente da gaiola $( \pm \mathrm{EPM})$ por filhotes testados em grupo e individualmente, na presença e ausência do animal adulto 


\section{Sumário}

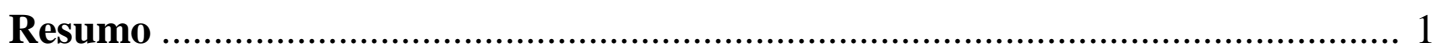

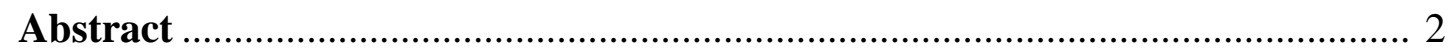

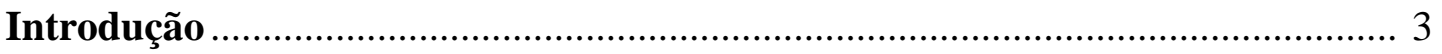

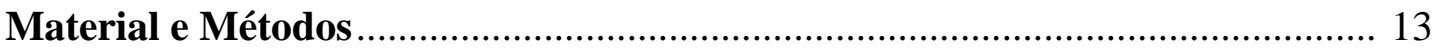

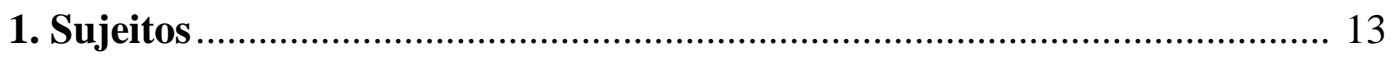

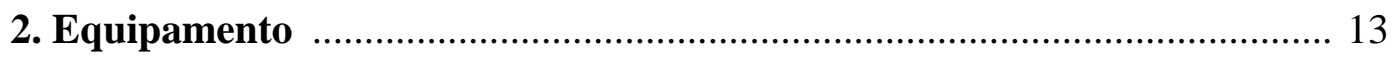

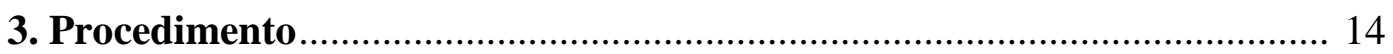

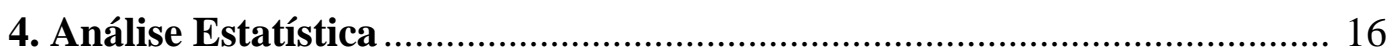

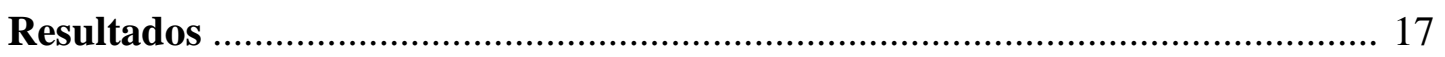

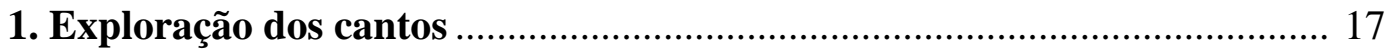

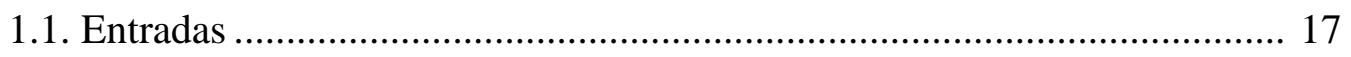

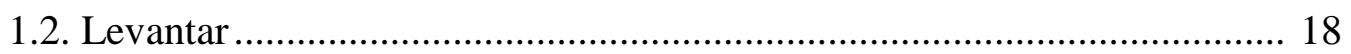

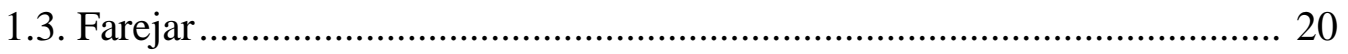

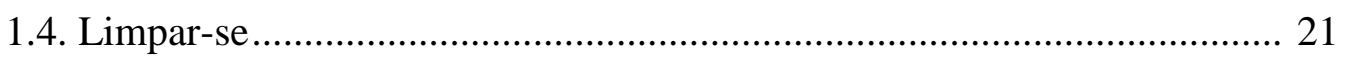

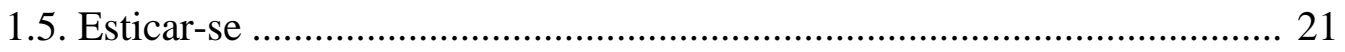

2. Exploração das áreas de uma parede .................................................... 21

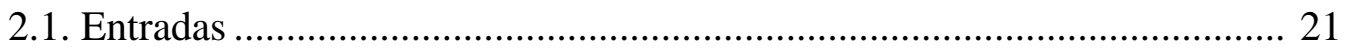

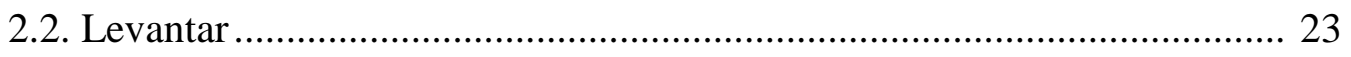

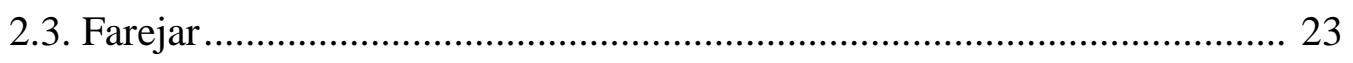

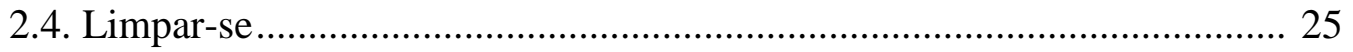

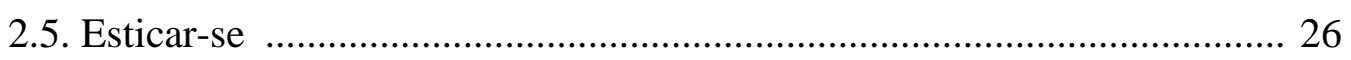

3. Exploração do quadrado em frente à gaiola ........................................... 26

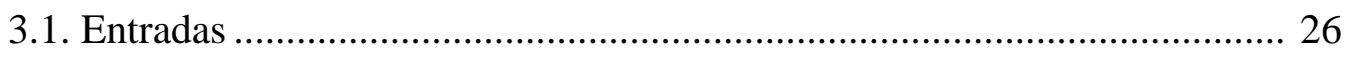

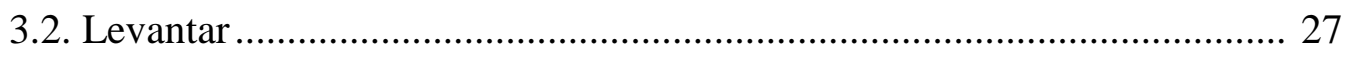

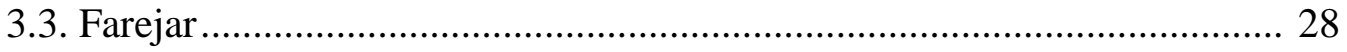

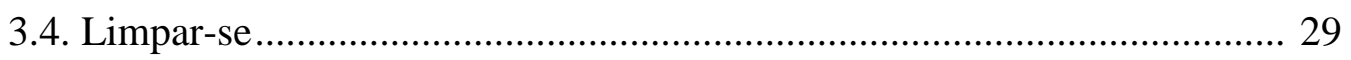

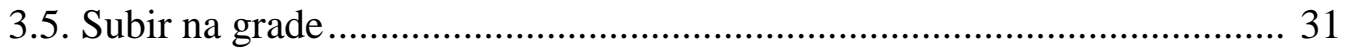

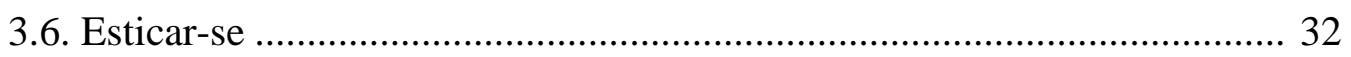

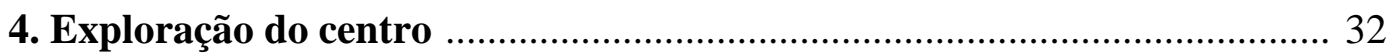

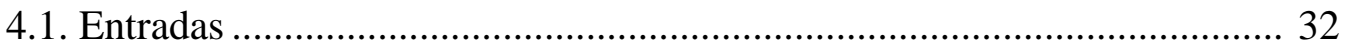

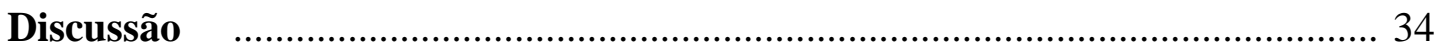

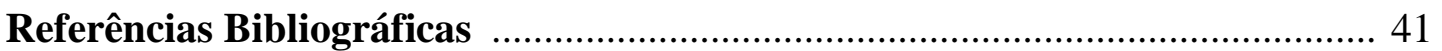




\section{Resumo}

Guilhermitti, A. C. Comportamento de filhotes de rato (Rattus norvegicus) em um campo aberto na presença e na ausência de animais adultos. 2011. 46f. Dissertação (Mestrado) - Faculdade de Filosofia, Ciências e Letras de Ribeirão Preto, Universidade de São Paulo. 2011.

Vários estudos realizados com roedores permitem analisar, entre outros fatores, as respostas dos animais à novidade, a emocionalidade e locomoção dos animais. Para tal, vários testes tem sido empregados e um dos mais utilizados é o do campo aberto. O presente estudo visa analisar o papel da presença de um animal adulto da mesma espécie, ou de espécie diferente, no comportamento exploratório e na ocupação das áreas de um campo aberto por filhotes de rato, testados em duas condições: agrupados ou individualmente. Na primeira condição os testes de exploração foram feitos em um campo aberto. Em uma das paredes do campo aberto foi acoplada uma gaiola que em diferentes momentos continha uma fêmea da mesma espécie (Rattus norvegicus), um macho da mesma espécie (ambos não familiarizados com os filhotes), a própria ama-de-leite ou uma fêmea de outra espécie, no caso, uma cobaia (Cavia porcelus). As sessões experimentais foram realizadas no vigésimo quinto dia de vida dos filhotes. Os animais foram divididos em cinco ninhadas compostas por oito filhotes cada uma: quatro machos e quatro fêmeas., testados juntos em uma única sessão. O primeiro grupo foi testado no campo aberto sem qualquer tipo de estímulo na gaiola. Os outros grupos foram testados, respectivamente, na presença da ama-de-leite, de uma outra rata, de um rato macho ou de uma cobaia. Na segunda condição, os sujeitos de outras cinco ninhadas foram testados nas mesmas circunstâncias, porém individualmente. Os resultados mostraram que a presença de um animal adulto altera a preferência pela ocupação dos cantos mais estruturados por filhotes de rato em campo aberto. Quando o adulto presente é um co-especifico, a tendência dos filhotes é de se aproximar do local onde o animal se encontra (gaiola). Na presença de um animal de outra espécie, a tendência é, num primeiro momento, de aproximação e posteriormente de permanência nos locais mais estruturados do campo aberto, como as áreas de duas paredes, igual aos testados com a gaiola vazia. Os animais apresentaram diferenças de comportamento devidos ao agrupamento. Os filhotes agrupados frequentaram mais a periferia do campo aberto e passaram mais tempo nestas áreas que os testados individualmente, que por sua vez tendem a se aproximar mais do adulto do que os testados em grupo. Na idade em que foram testadas, as fêmeas mostraram-se menos ansiosas que os machos. De um modo geral, a principal conclusão é a de que filhotes de rato expostos a um campo aberto na presença de um adulto, exibem preferência pelas proximidades do adulto quando este é um co-específico, tendendo a permanecer nas áreas mais estruturadas quando o animal presente é de outra espécie.

Palavras-chave: Comportamento exploratório; ansiedade; campo aberto; filhotes de rato; apego a adultos. 


\begin{abstract}
Guilhermitti, A. C. Behavior of rat pups (Rattus norvegicus) in an open field in the presence and absence of adult animals. 2011. 46f. Dissertação (Mestrado) - Faculdade de Filosofia, Ciências e Letras de Ribeirão Preto, Universidade de São Paulo. 2011.
\end{abstract}

Several studies with rodents allow us to analyze, among other factors, the responses of animals to novelty, emotionality and locomotion of animals. For this, several tests have been used and one of the most frequently used is the open-field. The present study aims at examining the role of the presence of an adult animal of the same species, or of a different species, in the exploratory behavior and the occupation of areas of an open-field by rat pups, tested in two conditions: grouped and individually. In the first condition, exploration tests were done in an open-field. In one wall of the open-field a cage was connected which, in different occasions, contained a female of the same species (Rattus norvegicus), a male of the same species (both unfamiliar to the pups), the dam or a female of another species, in this case, a guinea-pig (Cavia porcelus). The experimental sessions occurred at the twenty-fifth day of life of the of pups. The animals were divided into five eight-pup litters with four males and four females, which were tested together in a single session. The first group was tested in the open-field without any kind of stimulus in the cage. The other groups were tested, respectively, in the presence of the dam, another female, a male or a female guinea-pig. In the second condition, all subjects in a litter were tested under the same circumstances, but individually. The results showed that the presence of an adult animal changes the preference for the occupation of the more structured corners by rat pups in the open-field. When the animal in the cage was an adult co-specific, the tendency of the subjects was to approach the place where the adult animal was (the cage). In the presence of an animal of another species, the trend was, at first, to approach and subsequently to spent more time in the most structured corners of the open-field, areas with two walls. The animals showed behavioral differences due to grouping. The grouped pups went more often to the periphery of the open-field and spent more time in these areas than those tested individually, which, in turn, tended to be close to the adult longer than the grouped subjects. At the age they were tested, female infants were less anxious than males. In general, the main conclusion is that rat pups exposed to an open-field in the presence of an adult, exhibit a preference for the vicinity of the adult when it is a co-specific, tending to remain in the more structured areas when the cage was empty or when the animal in the cage belonged to another species.

Key-words: Exploratory behavior; anxiety; open-field; rat pups; attachment to adults. 


\section{INTRODUÇÃO}

O estudo do comportamento animal parece ter suas origens nas primeiras tentativas do homem primitivo de entender e tirar conclusões sobre a vida dos seres que o cercavam. A partir dos estudos sobre evolução, Charles Darwin foi sem dúvida o grande inspirador dos estudos biológicos do comportamento animal. Para ele, a evolução é um processo continuo, e todo comportamento possui uma base biológica. Sendo assim, as diferenças comportamentais entre o homem e outros animais seria puramente quantitativas (Kandel, 1976). Para Darwin, as características de cada animal estão intimamente ligadas à adaptabilidade do mesmo às condições do meio em que vive, e, portanto, os comportamentos de um homem, se comparados com os de um pingüim, não poderiam ser avaliados de forma a definir quais comportamentos são melhores ou piores do ponto de vista qualitativo, mas sim da necessidade que cada espécie possui de desenvolver e apresentar determinados comportamentos a fim de sobreviver às condições do meio onde vive. Os conhecimentos gerados à partir dos estudos darwinianos serviram de estímulo para que outros pesquisadores se interessassem por estudos comparativos do comportamento, levando também ao desenvolvimento de modelos animais que buscassem evidenciar a relação entre o sistema nervoso e o comportamento, trazendo a ideia de que todo comportamento, mesmo os mais complexos, derivam do sistema nervoso (Kandel, 1976).

Uma das classes comportamentais de fundamental valor adaptativo para os seres vivos é o comportamento exploratório. Para Berlyne (1960), o comportamento exploratório se define através das reações de investigação, reconhecimento e orientação do animal em relação ao espaço. $\mathrm{O}$ comportamento exploratório é vital à sobrevivência da maior parte dos animais e vem sendo estudado em muitas espécies, de insetos (Barnett, 1975) a primatas (Butler, 1953). A compreensão do comportamento exploratório possibilita esclarecer como se dá a interação interespecífica e intra-específica dos animais, desde os mais primitivos até os mais evoluídos e as relações que estes estabelecem com o meio ambiente.

O conhecimento sobre o comportamento dos animais, entre outras coisas, pode auxiliar no aumento da qualidade de ambientes de cativeiro, criação, reprodução, entre outros. Já os estudos sobre o comportamento exploratório realizados com roedores, permitem analisar, entre outros fatores, a resposta à novidade, os mecanismos neurais subjacentes a determinados comportamentos, as vias envolvidas, bem como o efeito comportamental de diferentes tratamentos.

Estudos mais amplos e detalhados, no entanto, foram realizados com roedores, dado o seu caráter altamente exploratório tanto em situação natural como em cativeiro, além do fato de esses animais apresentarem respostas emocionais primitivas como medo, ansiedade, e 
comportamento de filiação, semelhantes aos exibidos pelo homem. Ratos, quando exploram um ambiente, exibem uma preferência por áreas próximas à superfícies verticais (tigmotatismo), talvez como uma estratégia de defesa contra predadores aéreos (Grossen \& Kelly 1972), um comportamento selecionada no curso da evolução (Barnett, 1963) para evitar que esses roedores se tornem presas fáceis em locais abertos. Ainda, Barnett (1975) afirma que ratos, assim como outros pequenos mamíferos, têm a tendência não apenas de se mover em contato com uma superfície vertical, como também, adotar um canto para se alimentarem, evitando espaços abertos.

Além do amplo número de estudos com roedores, diversos estudos tem utilizado outras espécies para análise do comportamento exploratório. Por exemplo, Nicol et al. (2009), mostraram que galinhas poedeiras exibem clara preferência por locais mais estruturados e pelos cantos, deixando de ocupar as áreas centrais do galinheiro. Estudos sobre a estruturação do espaço e a preferência de ocupação também têm sido utilizados na análise do comportamento de gorilas e chimpanzés (Ross et al., 2009). Um dos achados mais comuns nesses estudos é a preferência pelos cantos com paredes, como relatado por Traylor-Holtz e Fritz (2005). Em suas análises sobre as preferências estruturais de chimpanzés, esses autores relataram que os animais muitas vezes se posicionavam nas áreas superiores perto das paredes da gaiola. Ross e Lukas (2006), em um de seus estudos sobre um ambiente não naturalista, descobriram que tanto chimpanzés quanto gorilas exibiam preferências significativas por lugares com maior estruturação, tais como cantos, áreas com portas, paredes com telas e paredes sólidas, bem como por áreas subjacentes com elementos permanentes, evitando espaços abertos. Embora raramente ocorram naturalmente no estado selvagem, os cantos mostram características compartilhadas com lugares que apresentam obstáculos próximos e espaçados, como árvores, arbustos e rochas, locais que possivelmente representam áreas de relativa segurança.

Em humanos, tem sido estudado o comportamento exploratório de crianças em ambientes de creche. No trabalho realizado por Campos de Carvalho e Mingorance (1999), sobre a ocupação do espaço por crianças pequenas em creche, utilizando ambientes com e sem estruturação, mostraram que em um arranjo aberto, sem zonas circunscritas (áreas delimitadas pelo menos em três lados por barreiras formadas por mobiliários, parede, desnível do solo, entre outros), as interações entre crianças são raras e elas tendem a se agrupar em volta do adulto e procurar interagir com o mesmo. Vários estudos apontam a importância dos aspectos físicos do ambiente para o desenvolvimento da criança, especialmente durante os três primeiros anos de vida, faixa etária na qual a linguagem verbal ainda não está totalmente desenvolvida e efetiva, na regulação de interações entre eles (Stambak \& Verba, 1986; Campos de Carvalho \& Rossetti Ferreira, 1993; Carvalho, 1997). Estudos sobre a estruturação e ocupação do espaço são 
importantes para a interpretação dos efeitos do enriquecimento ambiental e das preferências de ocupação, pois a partir destas observações é que se pode re-estruturar o ambiente para que este local propicie um maior bem-estar para seus ocupantes.

Os estudos sobre comportamento exploratório são de grande relevância por permitirem medir emocionalidade e locomoção, sendo frequentemente realizados com animais. Mais especificamente, com ratos, que se tornaram um modelo experimental para diversas análises do comportamento. Modelos de exploração forçada tem sido comumente utilizados no estudo do comportamento exploratório. Diversos estudos tem analisado o comportamento de ratos expostos a modelos que avaliam ansiedade. O labirinto em cruz elevado, um dos modelos mais utilizados para o estudo da ansiedade, além das medidas clássicas relacionadas aos comportamentos de ansiedade e locomoção, como os comportamentos de exploração dos braços abertos, analisa várias outras medidas. Por exemplo, foi proposto que o comportamento de avaliação de risco (esticar-se e mergulhar a cabeça) poderia representar uma medida relacionada a ansiedade. Além disso, o comportamento de levantar-se nas patas traseiras seria uma medida indicadora da atividade locomotora, enquanto a auto-limpeza indicaria um comportamento deslocado que o animal apresenta diante de uma situação conflitante (Cruz et al. 1994; Wall \& Messier, 2001).

Nos estudos que avaliam a estruturação do espaço ou as respostas dos animais a diferentes ambientes ou processos, as tomadas de decisões do animal são os fatores mais importantes da avaliação. Os testes de escolha simples são particularmente úteis para o estabelecimento de preferências ambientais; os estudos com animais domésticos são realizados a partir das preferências dos sujeitos pelo tipo de alimento, local de descanso, exploração dos materiais, calor, iluminação, escolha de companheiros e comportamento social. Muitos desses estudos tomam como medida de preferência o número de escolhas feitas por uma opção em relação às demais, ou a quantidade de tempo gasto pelo animal em cada opção. Entre os diversos tipos de testes comportamentais que têm sido empregados para medir emocionalidade ou locomoção em animais, um dos mais utilizados é o do campo aberto, inspirado nas propostas de Hall (1934), que se popularizou como teste de avaliação do comportamento exploratório (Simon et al., 1994; Poltyrev et al. 1996; Rex et al., 1996; Rebouças \& Schmidek, 1997; Schmitt \& Hiemke, 1998).

No teste do campo aberto, o animal é colocado em uma arena com área de formato variado, cercada por paredes opacas ou transparentes, iluminada por cima, e da qual não pode fugir. Por um certo tempo, que pode variar de experimento para experimento, são registrados os padrões de ambulação, tanto no centro como nas regiões periféricas (próximas as paredes) do campo aberto. Outros comportamentos, tais como levantar-se, limpar-se e defecar etc, também podem ser registrados e levados em conta nas análises. São comportamentos que podem refletir o 
estado emocional do animal frente a um novo ambiente. No teste do campo aberto, segundo alguns autores, o comportamento do animal é determinado pelo conflito entre a motivação para explorar e a aversão a lugares abertos, desprotegidos e iluminados (Whimbey \& Denenberg, 1967; Asano, 1986; Crusio et al., 1989). É um teste utilizado para analisar atividade e, com base nela, ansiedade em roedores. De modo coerente, drogas de perfil ansiolítico ou ansiogênico tendem, respectivamente, a aumentar ou diminuir a ambulação no campo aberto (Treit, 1985; Schmitt \& Hiemke, 1998).

Estudos do comportamento animal realizados por Martinez et al. (2003), analisando os efeitos da estruturação do campo aberto quadrado no comportamento exploratório de ratos adultos e filhotes, mostraram que animais testados, tanto individualmente como agrupados, exibem o mesmo padrão de ocupação e têm preferências pelas áreas circunscritas, isto é, pelos cantos do aparato. Os autores concluíram que o comportamento dos animais é sensível ao número de paredes havendo preferência por locais mais estruturados. Nesse mesmo sentido, Lamprea et al. (2008) realizaram um estudo no qual dividiram o campo aberto por áreas, de acordo com sua estruturação, considerando os quadrados centrais como uma área sem paredes circundantes, uma área composta pelos quadrados de uma parede, outra, composta pelos quadrados de duas paredes e um quarto tipo de área com três paredes, composto por um bloco de madeira delimitando um canto (de duas paredes) e se constituindo em uma terceira parede. $\mathrm{O}$ tempo de permanência e a frequência de entrada em cada uma das áreas foram as medidas utilizadas para avaliar a exploração dos animais. Os autores mostraram que ratos preferem caminhar ao longo das paredes adjacentes e evitam entrar na área central.

Além disso, o tempo que os ratos permaneceram em cada quadrado foi função do número de paredes. Os animais preferiram permanecer mais nos quadrados com três paredes do que nos de duas; preferiram ficar mais nos quadrados com duas paredes do que nos de uma só; e preferiram esses últimos aos quadrados sem qualquer parede. De acordo com os autores, nesse tipo de aparato, os ratos se utilizam da tigmotaxia para escolher onde e por quanto tempo permanecerão nas diferentes áreas do aparelho. Esse mecanismo também indicaria quais áreas do campo aberto os ratos consideram mais seguras.

O comportamento exploratório exibido pelos animais durante a exposição ao campo aberto tende a diminuir na medida em que este animal é re-exposto ao teste. Alterações de comportamento também podem ser observadas quando estes animais são expostos ao campo aberto na presença de estímulos novos. Wilson et al. (2000) relatam que a exposição aguda a um ambiente novo, como o campo aberto, gera um aumento dos níveis de ansiedade, que por sua vez, acarretam um aumento dos níveis de prolactina. A autora relata que, quando o animal é 
exposto por vários dias ao campo aberto, ocorre uma redução dos níveis de prolactina, possivelmente pelo fato da habituação ao local.

Nesses experimentos, foram testados ratos fêmeas e machos no campo aberto, habituando-os e expondo-os à presença de um co-específico do mesmo sexo ou ao aparato sem qualquer outro estímulo. A partir disso, os autores mediram os níveis de prolactina e o comportamento de brincar dos filhotes. Os resultados mostraram que, com cinco dias de habituação ao local de teste, os níveis de prolactina baixaram e o comportamento de brincar ocorreu após um dia de habituação. Os animais que foram testados na presença de um coespecifico apresentaram níveis de prolactina menores do que os animais testados sozinhos. A presença de co-específicos em uma situação estressante pode ter reduzido o estresse, fazendo com que o animal deixasse de perceber o ambiente como um estimulo aversivo e voltasse sua atenção para o animal ali presente.

Podemos supor que a interação social com um co-específico possa ter reduzido o estresse normalmente associado à exposição aguda ao campo aberto, como mostram as medidas dos níveis de prolactina (Wilson et al., 2000). A habituação ao campo aberto também resultou em um comportamento de brincar mais frequente, pois como o animal já tinha explorado o campo aberto por cinco dias e podia passar mais tempo envolvido na exploração do novo elemento, o parceiro social (co-especifico). Além disso, como a intensidade da interação social aumentou (brincavam mais), os níveis de prolactina diminuíram. Já nos estudos de Hennessey (1986), os níveis de cortisol em macacos-esquilo fêmeas mantiveram-se inalterados durante a exposição a um ambiente novo, com ou sem um co-específico (Hennessey, 1986).

Em estudos realizados com seres humanos, os sujeitos foram submetidos a uma tarefa de computador na qual receberam falsos feedback negativos; o apoio social e o incentivo de um familiar durante a apresentação dos feedbacks negativos fizeram com que os níveis de cortisol e prolactina fossem reduzidos (Biondi \& Picardi 1999). Em um experimento similar, seres humanos que receberam apoio social de outro indivíduo durante uma tarefa de desafio no computador tinham níveis mais baixos de cortisol quando comparados com os de participantes que não receberam nenhum tipo de apoio social (Thorsteinsson, et al. 1998).

Um outro estudo com seres humanos mostrou que o estresse psicológico de um sujeito, provocado pela situação de exposição deste para falar dirigindo-se a uma plateia, foi reduzido quando um familiar (apoio social) estava presente. Isso ficou evidente pelas medidas mais baixas dos níveis de cortisol (Kirschbaum, et al. 1995). Biondi e Picardi (1999) sugeriram que as respostas neuroendócrinas a condições estressantes podem ser ditadas, pelo menos em parte, pelas interpretações que o sujeito tem do evento e pelo apoio social que outro indivíduo possa oferecer. Os experimentos nos levam a crer que um ambiente estressante pode ser interpretado 
como menos estressante se um apoio social estiver disponível, como no caso da presença de um co-específico.

Vários estudos comportamentais foram realizados para avaliar as diferentes respostas dos animais expostos à presença de animais da mesma família, de co-específicos desconhecidos e de animais de outras espécies para analisar as preferências de ocupação de espaço e os comportamentos de filiação envolvidos nestas situações. Os estudos de Latané et al. (1971) não mostraram quaisquer diferenças em relação às medidas sociais de proximidade entre coespecíficos da mesma família e de desconhecidos.

Por outro lado, ratos observados nas proximidades de um animal da mesma família parecem ter estabelecido algum tipo de relacionamento preferencial (Cirulli, et al. 1996). Esses animais realmente exibem maior tempo em proximidade, mantendo interações de filiação que caracterizam o comportamento discriminado como apego, conforme definição de Cirulli et al. (1996). De acordo com File (1990), o medo e a curiosidade em relação a ambientes novos competem com a atração social por um co-específico e geram um estado emocional bem mais intenso que a necessidade de interação social daquele momento. A fim de identificar as diferenças entre as preferências de proximidade por um co-específico da família ou qualquer outro co-específico, Terranova (1999) colocou os ratos em uma gaiola do mesmo tipo e tamanho daquela em que os animais habitavam e utilizou um grupo de animais sem nenhum estimulo na gaiola como grupo controle. Os resultados mostraram que os ratos testados na presença de um co-específico da mesma família buscaram mais interações sociais que quando expostos a coespecíficos estranhos, o que ficou particularmente evidenciado no grupo das fêmeas.

Um co-específico desconhecido pode alterar a ativação do eixo hipotálamo-pituitáriaadrenal em resposta a estímulos estressantes (Hennessy, 1986). Em primatas, a proximidade de um membro do grupo social pode reduzir a resposta do eixo HPA a estímulos aversivos de macacos alojados sozinhos e expostos a estímulos estressores, tais como uma serpente (Mineka et al. 1980; Vogt et al.1981).

O sexo dos animais, também pode exercer uma grande influencia sobre as diferentes respostas comportamentais frente a diferentes estímulos. Machos e fêmeas jovens, quando testados em um campo aberto responderam da mesma forma em relação à presença de um coespecífico (Wilson et al., 2000), porém, em outras situações de teste, Smith et al. (1998) verificaram que, após a puberdade, os ratos machos utilizavam táticas defensivas mais frequentemente durante o jogo, enquanto que as fêmeas não alteraram suas táticas de jogar conforme iam ficando mais velhas. Os resultados de Cirulli et al. (1996) confirmam estudos anteriores (Shors \& Wood, 1995), nos quais, comparando o comportamento de fêmeas ao de 
machos, observou-se que aquelas parecem ser mais sensíveis do que esses quanto à familiaridade com os co-específicos apresentados.

As diferenças devidas ao sexo exibidas nos comportamentos emocional e exploratório têm sido documentadas em uma variedade de mamíferos, incluindo o homem (Archer, 1975; Johnston \& File, 1991). Na verdade, o sexo tem mostrado interagir com uma complexidade de estímulos (Russel, 1977). Em geral, as fêmeas mostram uma maior preferência pela novidade que os machos, e, portanto, estão mais voltadas a explorar ambientes novos. Além disso, nas respostas fisiológicas a estressores exógenos, as fêmeas apresentaram níveis basais de glicocorticóides mais elevados que os dos machos, além de uma maior amplitude de respostas aos estressores (Kitay, 1961; Critchlow et al., 1963).

Em referência a estudos do comportamento de animais expostos a situações ansiogênicas, um importante aspecto a ser considerado é o fato de que os comportamentos podem ser diferentes quando se levar em conta a idade dos animais. Animais por volta da adolescência respondem de forma diferente a um mesmo estímulo quando comparados com animais de idades variadas (Terranova et al., 1998). De acordo com os autores desse estudo, ratos e camundongos diferem marcadamente em vários aspectos de seu comportamento e fisiologia em função da idade. A faixa etária considerada como adolescência caracteriza-se por níveis elevados de filiação social e interações lúdicas compostas basicamente por brincadeiras (Terranova et al. 1993). Nessa linha, Guillet \& Kellogg (1988) relataram que as respostas de estresse a um ambiente novo são expressas no rato a partir dos seus 28 dias de idade, ou seja, durante a fase da pré-puberdade. No entanto, as respostas comportamentais para estas condições ansiogênicas, avaliadas por meio de testes de interação social, aparecem um pouco mais tarde, na puberdade.

De acordo com Terranova et al. (1998), as variáveis sociais parecem desempenhar um papel muito importante na modulação das respostas comportamentais e fisiológicas à novidade na fase imediatamente anterior à adolescência. Tais respostas comportamentais e fisiológicas são diferentes das exibidas pelo indivíduo na fase adulta. $\mathrm{Na}$ fase adulta, devido às disputas por domínio territorial, parceria sexual e alimentação, o animal pode reconhecer um co-específico como uma ameaça possível. Um animal de outra espécie, mesmo não sendo um predador natural, também pode representar risco e, assim, aumentar os níveis de ansiedade.

Do ponto de vista evolutivo, as espécies que sofrem pressão de predação desenvolveram adaptações específicas que aumentam sua probabilidade de sobrevivência. Essas adaptações são evidentes para detecção, reconhecimento, esquiva e defesa contra predadores. A maioria das espécies animais, incluindo os seres humanos, apresenta comportamentos defensivos quando expostos a situações que representem ameaça possível. Dentre esses comportamentos incluem-se 
luta, fuga e avaliação de risco, todas respostas adaptativas à situações potencialmente ameaçadoras a que esses são expostos.

Os estudos sobre os comportamentos defensivos de roedores em situações experimentais foram pensados e validados para contribuir na compreensão da ansiedade humana, em sua extensão do normal ao patológico (Bakshi, V. P. \& Kalin, N. H. 2002, Van der Staay, F. J. 2006). Em roedores, o comportamento de defesa ocorre em resposta a ameaças (reais ou potenciais) ou estímulos aversivos: presença de predadores ou de co-específicos, local em que um predador foi anteriormente encontrado, estímulos que sinalizam o predador (ex., odor), choque nas patas, jatos de ar dirigidos aos olhos, e muitos outros. De acordo com Blanchard et al. (1989), na ausência do predador, o padrão comportamental de defesa é muito diferente do que ocorre na presença do predador.

Sugere-se a partir de alguns estudos que o componente motivacional de muitos comportamentos defensivos é pré estabelecido para uma variedade de espécies de mamíferos (Blanchard \& Blanchard, 1984). Nos animais, a ocorrência de estímulos apropriados acarreta ataque ocasionado, por exemplo, por disputas de território e dominância social (Wilson, 1975). Em humanos, os padrões de agressão estão mais envolvidos com disputas pelo uso de propriedades, bens e privilégios (Felson, 1983). Existem outros comportamentos que envolvem os mesmos padrões de motivação tanto no homem como outros mamíferos, como por exemplo, os relacionados ao medo, os quais podem ser produzidos pelas mesmas classes de estímulos (Wilson, 1975).

O padrão comportamental de autodefesa frente a um perigo potencial é diferente do observado nas reações de ataque de predadores ou de um co-específico. Tal padrão não inclui somente respostas a ameaças, mas sua característica essencial parece ser a avaliação de risco, que geralmente não ocorre em resposta a um ataque. A avaliação de risco inclui uma análise do meio, caracterizada por uma diminuição da ambulação, culminando em contato e manipulação dos estímulos potencialmente ameaçadores (Blanchard \& Blanchard, 1989). Este padrão de avaliação de risco é um componente essencial na redução de comportamentos defensivos, fornecendo assim, informações indicando que a ameaça não é iminente. Por outro lado, quando a avaliação de risco fornece informações que confirmam, identificam e localizam uma situação de perigo, o padrão comportamental passa de um padrão "ansiedade/defesa" para outro mais eficaz de "medo/defesa" (Blanchard \& Blanchard, 1988).

A resposta de defesa natural (incondicionada) expressa-se de forma semelhante em todas as espécies de mamíferos, inclusive nos roedores, e consiste das seguintes reações: fuga, congelamento motor, ameaça defensiva, ataque defensivo e avaliação de risco (Blanchard, 2001). O fato de serem incondicionados implica que cada uma destas respostas pode ser produzida em 
ratos selvagens ou de laboratório sem experiência prévia. Particularmente, a exposição do rato a um gato, produz congelamento motor, comportamentos de esquiva e elementos de avaliação de risco, tais como orientação em relação ao predador, compatíveis com a esquiva e o congelamento motor. (Blanchard \& Blanchard, 1971).

A exposição dos ratos à um gato vivo produz alterações comportamentais típicas, tais como saltos e congelamento, diminuição significativa do tempo gasto perto do compartimento ocupado pelo predador, além da ativação de estruturas importantes do circuito aversivo, tais como núcleos da amídala, hipotálamo e da substância cinzenta periaquedutal dorsal (Beijamini \& Guimarães, 2006). Outros estudos, empregando um gato vivo ou o odor do predador como estimulo de medo inato, também demonstraram a ativação das estruturas relacionadas a comportamentos de defesa quando os animais eram expostos a estes estímulos. (Canteras et al., 1997; Canteras \& Goto, 1999; Dielenberg, 2001).

A relação destas estruturas com o comportamento de defesa, está expressa em experimentos mostrando, por exemplo, que a lesão da amídala resulta em uma diminuição da resposta de defesa dos ratos ao predador (Blanchard \& Blanchard, 1972). Outro estudo do mesmo grupo (Blanchard et al., 2003) mostrou que lesões do núcleo pré-mamilar dorsal produziram dramática redução no congelamento, esquiva e avaliação de risco frente a odor de gato, e redução do congelamento, com aumento de atividade e de avaliação de risco frente à exposição ao gato.

Os paralelos estabelecidos entre padrões de comportamento defensivo e de ataque em mamíferos, incluindo os de medo, ansiedade e agressividade em humanos, sugerem que os modelos animais podem ser extremamente úteis no estudo das relações primitivas de conservação dos sistemas neurocomportamentais, abrangendo vários estados emocionais (Blanchard \& Blanchard, 1988).

As respostas dos animais a diferentes estímulos, sejam um co-específico, um possível predador, ou mesmo um ambiente com diferentes estruturações, podem ser influenciadas pela condição em que estes animais se encontram frente ao potencial estimulo, por exemplo, em grupo ou isolados. Assim, ratos machos alojados individualmente apresentam níveis mais elevados de prolactina que animais alojados em grupos (Gambardella, et. al 1994). Em experimentos realizados com fêmeas de macacos-esquilo, os animais foram expostos a um paradigma de medo condicionado e os exames realizados mostraram que os animais testados em grupo apresentaram níveis mais baixos de cortisol do que os testados individualmente (Stanton et al., 1985).

Os experimentos de Hurst et al. (1999) mostraram que ratos alojados individualmente têm maior tendência a interações sociais do que os alojados em grupo. Os autores sugerem que o 
estresse estava aumentado nos animais alojados em grupo, o que permite considerar o fato de que os comportamentos se alteram quando os animais estão agrupados ou alojados individualmente.

Em outra direção, Botelho et al. (2007), em um estudo realizado em nosso laboratório, mostrou que tanto ratos alojados isolados como agrupados em grande número apresentam mais ansiedade, conforme medida no labirinto em cruz elevado, do que os agrupados em números menores. Nesse estudo, ratos machos alojados em gaiolas comerciais individualmente, aos pares, em grupos de três, dezesseis ou vinte e quatro exploraram os braços abertos menos do que os alojados em grupos de quatro, seis, oito ou doze animais. Esses dados ocorriam quando os animais eram alojados nessas condições por apenas 24 horas ou quando permaneciam nessas condições por 14 dias.

Todos os dados aqui apresentados mostram que ao estudar o comportamento exploratório, é conveniente observar as respostas dos animais em diferentes condições de agrupamento (por exemplo, alojados individualmente ou agrupados), levando em consideração as diferenças nas respostas que podem ser devidas ao sexo do animal, bem como à idade dos indivíduos e às situações as quais estão expostos. Além disso, permitem levantar as questões que se seguem. (1) A preferência de filhotes de ratos por determinadas áreas do campo aberto pode ser alterada pela presença de um animal adulto, co-específico ou não? Os padrões de ocupação do campo aberto são diferentes quando os filhotes são testados individualmente ou em grupo? Machos e fêmeas apresentam padrões iguais de exploração?

Assim, o objetivo do presente estudo é analisar o papel da presença de um animal adulto (da mesma espécie ou de espécie diferente) no comportamento exploratório e na ocupação das áreas de um campo aberto por filhotes de rato, machos e fêmeas, testados em grupos ou individualmente. 


\section{MATERIAIS E MÉTODOS}

\section{Sujeitos.}

Foram utilizados filhotes de ratos de uma derivação Wistar, 80 machos e 80 fêmeas, provenientes do Biotério Central do Campus de Ribeirão Preto da Universidade de São Paulo. Os animais foram alojados em gaiolas de polipropileno (40 x 40 x $17 \mathrm{~cm})$, em ninhadas de oito filhotes (quatro fêmeas e quatro machos) com uma fêmea parida no mesmo dia do nascimento deles (ama-de-leite). Os filhotes permaneceram no biotério do laboratório desde o primeiro dia de vida até o vigésimo quinto dia, quando foram testados. Na realização dos experimentos, também foram utilizados um rato Wistar macho de aproximadamente $210 \mathrm{~g}$, uma rata fêmea de peso e idade aproximados ao da ama-de-leite, uma cobaia fêmea branca, de aproximadamente $250 \mathrm{~g}$. Todos os sujeitos utilizados no experimento receberam água e comida à vontade e o biotério foi mantido em um ciclo de claro-escuro de 12 horas (luzes acesas às $7 \mathrm{~h}$ da manhã), com a temperatura mantida entre 24 e $27^{\circ} \mathrm{C}$. A cobaia, também proveniente do Biotério Central, era mantida em sala separada da dos ratos (exceto quando necessário para os testes), para evitar que sinais de sua presença (odores, vocalizações) interferissem no comportamento dos animais experimentais.

\section{Equipamentos.}

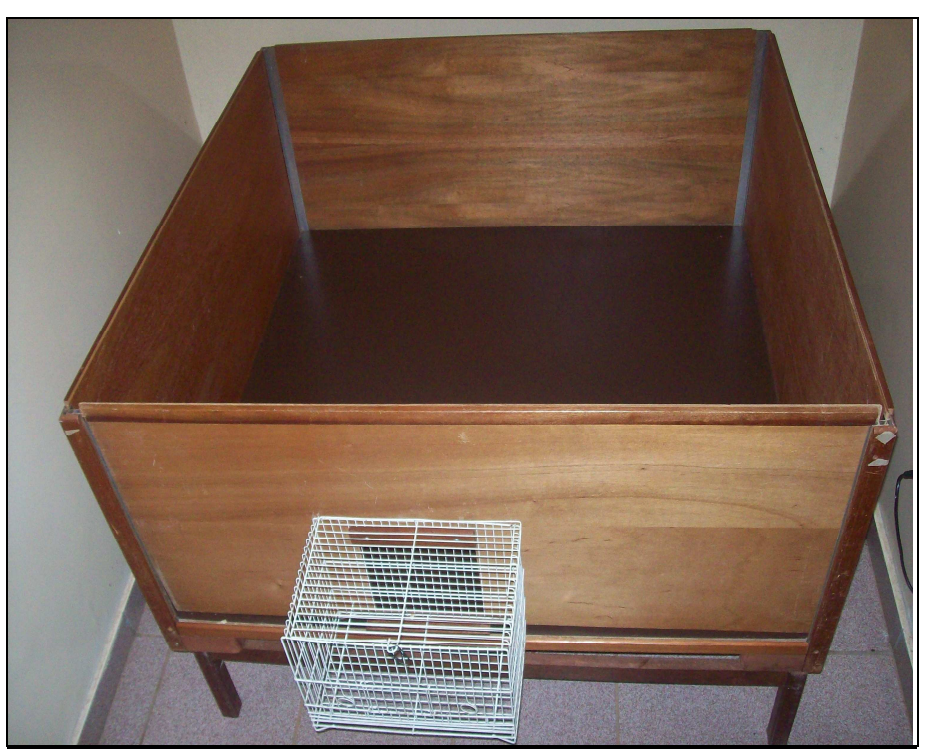

Figura 1. Campo aberto com gaiola de pássaros acoplada a uma das paredes.
Os testes de exploração foram feitos em um campo aberto. $\mathrm{O}$ aparelho consiste de uma caixa quadrada de madeira $(120 \times 120 \mathrm{~cm})$ com piso de fórmica marrom escura cercada por paredes laterais de madeira escura com $40 \mathrm{~cm}$ de altura. Em uma das paredes do campo aberto, foi anexada do lado de fora uma gaiola de pássaros $(32$ × 26 x $22 \mathrm{~cm}$ ) na qual se podia colocar um animal adulto (fêmea, macho, ou a cobaia), como ilustra a Figura 1. As grades de uma das paredes da gaiola estavam em contato com o interior do campo aberto e através delas era possível um contato entre os animais. 
Suspensa acima da região central do campo aberto havia uma câmera de vídeo (Gradiente GCP-165cr, Brasil), acoplada a um monitor na sala adjacente à sala de teste. O monitor era ligado a um computador com o qual se podia efetuar os registros tanto no momento do teste ou posteriormente, usando a gravação em vídeo. A sala era iluminada por uma lâmpada incandescente de $60 \mathrm{~W}$, que projetava aproximadamente 30 lux no centro do campo aberto.

\section{Procedimento.}

O experimento foi realizado em duas etapas. Na primeira, todos os animais de uma mesma ninhada foram testados de uma só vez. Na segunda etapa, os animais de uma ninhada foram testados individualmente. As sessões experimentais foram realizadas no vigésimo quinto dia de vida dos filhotes, data em que já haviam desmamado e em que a motivação para explorar está mais evidenciada (Genaro \& Schmidek, 2002). Cada animal foi marcado em diferentes locais do dorso com cores diferentes de pincel atômico: as fêmeas foram marcadas de vermelho e os machos de azul.

Em cada etapa, duas ninhadas foram testadas em cada condição. O primeiro grupo de duas ninhadas (controle) foi testado no campo aberto com a gaiola vazia. Os outros grupos de duas ninhadas foram testados com diferentes adultos presentes na gaiola: respectivamente, a ama-de-leite, uma fêmea, um rato macho e uma cobaia. Com exceção da ama, os sujeitos nunca tiveram contato prévio com os outros animais adultos.

Todos os animais foram testados em sessões de cinco minutos, contados a partir do momento em que eram colocados no centro do campo aberto e cada animal foi testado apenas uma vez. Antes de cada teste, para evitar que os animais usassem pistas olfativas dos animais testados previamente, o campo aberto era limpo com uma solução de álcool (5\%) e enxugado com um pano seco.

Os dados foram registrados por uma câmera de vídeo fixada em suporte no teto, capaz de abarcar a imagem de todo o campo aberto. Por ocasião da análise, um gabarito de plástico transparente colocado sobre a tela do monitor dividia a imagem do piso do campo aberto em 36 quadrados de $20 \mathrm{~cm}$ de lado, permitindo a localização precisa dos deslocamentos do animal e a localização exata dos comportamentos exibidos em cada um dos quadrados. O programa utilizado para registrar as análises foi o X-PloRat. (O software pode ser baixado do site http://scotty.ffclrp.usp.br/download.php?view.1) 
Após a análise dos eventos comportamentais ocorridos em cada quadrado, os dados foram agrupados conforme uma de quatro regiões: (1) área central com 16 quadrados sem qualquer parede, (2) área periférica com uma parede adjacente com 15 quadrados (excetuando o

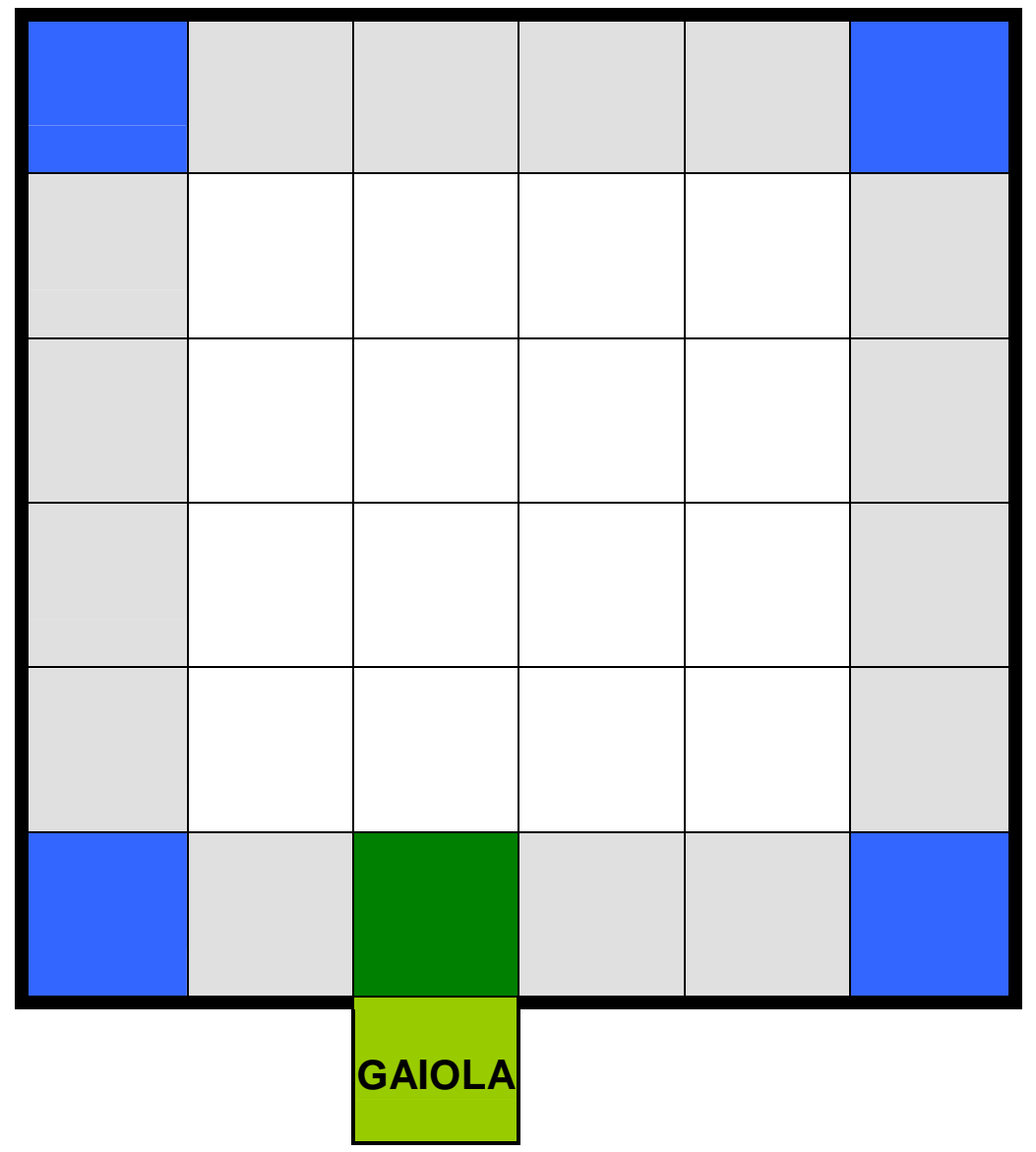

Figura 2. Representação esquemática do campo aberto.

Os quadrados azuis representam a área dos cantos (com duas paredes), os cinzas, as áreas com uma parede, os em branco, as áreas do centro do campo aberto (sem paredes), o verde escuro, a área defronte a gaiola, enquanto esta é indicada pelo quadrado verde claro externo ao campo aberto. A porta da sala está localizada à direita. quadrado defronte a gaiola), (3) área com duas paredes, representada pelos quatro cantos do aparato e, finalmente, (5) o quadrado defronte a gaiola, com uma parede, considerando-se a grade da gaiola como uma parede (Figura 2).

Para cada quadrado, foram registradas as frequências de entradas e o tempo gasto nos mesmos, juntamente com a frequência e o tempo gasto nos seguintes comportamentos: (1) farejar o ambiente, outros filhotes (no caso dos animais testados em grupo) ou o adulto (através das grades), (2) levantarse, (3) subir na grade da gaiola, (4) limpar-se e (5) esticar-se. O comportamento de limpar-se foi

definido como qualquer movimento feito com as patas tocando partes do corpo ou com os dentes, como se estivessem coçando áreas do corpo. O de levantar-se era registrado toda vez que o animal se apoiava nas patas traseiras, inclinado ou não. Farejar era registrado quando o sujeito exibia movimentos de farejar dirigidos tanto a partes do ambiente como a um outro animal. Esticadas eram registradas toda vez que o animal, mantendo a posição das patas traseiras, deslocava as dianteiras e aumentava seu comprimento; o comportamento era registrado no quadrado onde estavam as patas traseiras. Finalmente, o comportamento de subir nas grades era registrado toda vez que um sujeito efetivamente escalava as grades ou quando ficava nas patas traseiras, levantava-se e agarrava as grades com as patas dianteiras.

Para todos os dados, inicialmente calcularam-se as médias de cada sujeito para as ocorrências em cada quadrado de uma dada área, somando-se os valores de todos os quadrados 
de uma dada área e dividindo-se o total pelo número de quadrados da área. A média de cada sujeito de um dado grupo contribuía para o cômputo da média daquele grupo para aquela área.

\section{Análise estatística.}

Os dados são apresentados como médias ( \pm E. P. M.) dos sujeitos para uma dada área. Como primeira abordagem, os dados foram submetidos a uma análise de variância de quatro vias, tendo as áreas do campo aberto como um dos fatores. Posteriormente, os dados foram submetidos a análises de variância de três vias, tendo como fatores o agrupamento (agrupados vs. individuais), o gênero (machos vs. fêmeas) e a presença do adulto na gaiola (cinco níveis: vazia, ama, fêmea, macho e cobaia). Quando a análise indicava que um fator não era significativo, os sujeitos eram reagrupados e os dados submetidos a uma análise de variância de duas vias. $\mathrm{O}$ mesmo procedimento era empregado quando dois fatores não apresentavam significância, resultando em uma análise de variância de uma via. Em todos os casos, quando apropriado, empregou-se o teste de comparações múltiplas de Holm-Sidak para detectar diferenças entre as médias de grupos. Em todos os testes foi utilizado como nível de significância $\mathrm{P}<0,05$. 


\section{RESULTADOS}

\section{Exploração dos cantos}

\subsection{Entradas}

FREQUÊNCIA. A Figura 3 mostra a frequência de entradas nos cantos do aparato. A Anova de três vias mostrou que ocorreram efeitos devidos ao animal presente na gaiola $\left(\mathrm{F}_{[4,136]}=8,154, \mathrm{P}<\right.$ 0,001) e ao agrupamento $\left(\mathrm{F}_{[1,136]}=10,049, \mathrm{P}=0,002\right)$, mas não devidos ao gênero $\left(\mathrm{F}_{[1,136]}=0,593\right.$, $\mathrm{P}=0,443$ ), sobre a frequência de entradas nas áreas de duas paredes. Assim, ratos machos e fêmeas de cada grupo foram agrupados e os dados submetidos a uma Anova de duas vias. Esta análise mostrou efeitos gerais do animal presente na gaiola $\left(\mathrm{F}_{[4,146]}=8,199, \mathrm{P}<0,001\right)$ e do tipo de agrupamento durante o teste $\left(\mathrm{F}_{[1,146]}=10,493, \mathrm{P}=0,001\right)$ sobre a frequência de entradas nos quadrados com duas paredes. Mostrou ainda que existe uma interação entre as variáveis tipo de animal presente na gaiola e tipo de agrupamento durante o teste $\left(\mathrm{F}_{[4,146]}=4,736, \mathrm{P}=0,001\right)$. $\mathrm{O}$ teste de comparações múltiplas de Holm-Sidak indicou que os filhotes testados agrupados com a cobaia na gaiola entraram mais nos cantos do que os testados com a gaiola vazia (controles), não havendo diferenças entre esses últimos e os demais grupos testados agrupados. Não foram constatadas diferenças com os controles entre os animais dos demais grupos quando testados individualmente, independentemente do tipo de animal na gaiola. Ainda, os animais testados agrupados com o macho e a cobaia presentes na gaiola entraram mais frequentemente nos cantos do que os testados individualmente com esses mesmos animais.

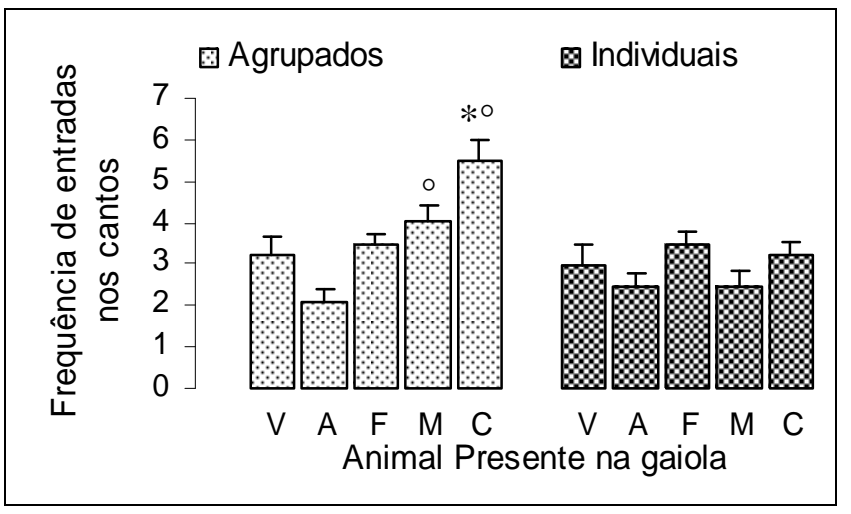

Figura 3. Médias das frequências de entradas nos cantos do campo aberto ( \pm EPM) dos filhotes testados em grupo e individualmente no campo aberto, na presença e ausência do animal adulto.

V, Gaiola vazia (controle); A, ama-de-leite; F, fêmea; M, macho; C, cobaia; *, Diferente do respectivo grupo controle;, , diferente dos individuais.

TEMPO: A Figura 4 mostra o tempo gasto nos cantos do aparato. Uma Anova de três vias mostrou que ocorreram efeitos devidos ao animal presente na gaiola $\left(\mathrm{F}_{[4,136]}=12,957, \mathrm{P}<0,001\right)$ mas não devidos ao gênero $\left(\mathrm{F}_{[1,136]}=0,831, \mathrm{P}=0,363\right)$ e nem ao agrupamento $\left(\mathrm{F}_{[1,136]}=2,333, \mathrm{P}=\right.$ 0,129 ) sobre o tempo gasto nos quadrados com duas paredes. A Anova mostrou também que não houve interação entre os fatores. Por essa razão, todos sujeitos foram agrupados somente levando-se em conta o animal presente na gaiola durante o teste e os resultados submetidos uma 
Anova de uma via. Esta análise mostrou que houve efeitos do animal presente na gaiola $\left(\mathrm{F}_{[4,151]}=\right.$ 13,345, $\mathrm{P}<0,001)$ sobre o tempo gasto nos quadrados com duas paredes. O teste de comparações múltiplas de Holm-Sidak indicou que os animais testados na presença do macho, da ama ou da fêmea na gaiola, passaram menos tempo nos cantos quando comparados com o grupo testado com a gaiola vazia. Estes, por sua vez, não diferiram dos filhotes testados na presença da cobaia na gaiola.

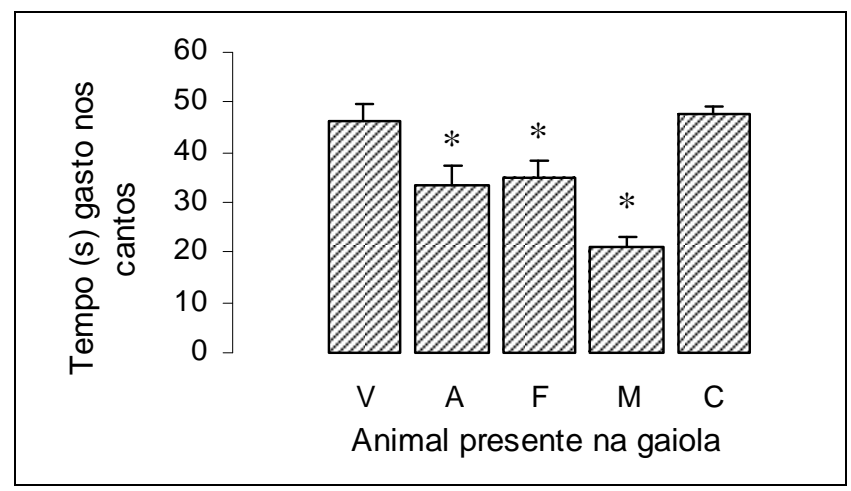

Figura 4. Médias do tempo gasto nos cantos do campo aberto ( \pm EPM) pelos filhotes testados na presença e ausência do animal adulto.

V, Gaiola vazia (controle); A, ama-de-leite; F, fêmea; M, macho; C, cobaia.; * Diferente do grupo controle (gaiola vazia).

\subsection{Levantar}

FREQUÊNCIA: A Tabela 1 mostra a frequência de levantadas nos cantos do aparato. Uma Anova de três vias mostrou efeitos devidos ao animal presente na gaiola $\left(\mathrm{F}_{[4,136]}=3,280, \mathrm{P}<0,013\right)$ e ao gênero $\left(\mathrm{F}_{[1,136]}=4,062, \mathrm{P}=0,046\right)$, mas não ao tipo de agrupamento $\left(\mathrm{F}_{[1,136]}=3,137, \mathrm{P}=0,079\right)$, sobre a frequência de levantar-se. Por isso, os sujeitos foram reagrupados e os dados analisados com uma Anova de duas vias tendo como fatores o animal presente na gaiola e gênero. Esta análise mostrou efeitos gerais do gênero $\left(\mathrm{F}_{[1,146]}=4,043, \mathrm{P}=0,046\right)$ e do animal presente na gaiola $\left(\mathrm{F}_{[4,146]}=3,213, \mathrm{P}=0,015\right)$ sobre a frequência de levantar-se; não ocorreu interação entre gênero e tipo de animal presente na gaiola $\left(\mathrm{F}_{[4,146]}=0,181, \mathrm{P}=0,948\right)$. $\mathrm{O}$ teste de comparações múltiplas de Holm-Sidak indicou que as fêmeas levantam-se com mais frequência que os machos em todas as condições e que nenhum dos grupos foi diferente dos filhotes testados com a gaiola vazia.

TEMPO: A Tabela 1 mostra o tempo gasto levantando-se nos cantos do campo aberto. Uma Anova de três vias mostrou efeitos devidos ao animal presente na gaiola $\left(\mathrm{F}_{[4,136]}=3,441, \mathrm{P}<\right.$ $0,010)$ e ao agrupamento $\left(\mathrm{F}_{[1,136]}=3,991, \mathrm{P}=0,048\right)$ mas não ao gênero $\left(\mathrm{F}_{[1,136]}=3,235, \mathrm{P}=\right.$ $0,074)$ sobre a frequência de levantadas. Por essa razão os sujeitos foram reagrupados e os dados analisados com uma Anova de duas vias tendo como os fatores: agrupamento e animal presente na gaiola. Esta análise mostrou efeitos gerais do agrupamento $(F[1,146]=4,197, P=0,042)$ e do animal presente na gaiola $(\mathrm{F}[4,146]=3,491, \mathrm{P}=0,009)$ sobre o tempo gasto levantando-se, mas não interação entre os fatores $\left(\mathrm{F}_{[4,146]}=1,303, \mathrm{P}=0,272\right)$. $\mathrm{O}$ teste de comparações múltiplas 
Tabela 1 - Comportamentos de filhotes de rato, fêmeas e machos, nos cantos do campo aberto, na presença e ausência de animais adultos na gaiola.

Os dados representam a média individual da ocupação dos cantos e são apresentados como média \pm E. P. M.

Animal presente na gaiola durante o teste

\begin{tabular}{|c|c|c|c|c|c|c|c|c|c|c|}
\hline \multirow[b]{2}{*}{ Comportamentos } & \multicolumn{2}{|c|}{ Vazia } & \multicolumn{2}{|c|}{ Ama } & \multicolumn{2}{|c|}{ Fêmea } & \multicolumn{2}{|c|}{ Macho } & \multicolumn{2}{|c|}{ Cobaia } \\
\hline & Fêmeas & Machos & Fêmeas & Machos & Fêmeas & Machos & Fêmeas & Machos & Fêmeas & Machos \\
\hline \multicolumn{11}{|c|}{ Filhotes testados agrupados } \\
\hline Levantadas & $0,88 \pm 0,23$ & $0,50 \pm 0,19$ & $0,50 \pm 0,19$ & $0,14 \pm 0,14$ & $0,75 \pm 0,16$ & $0,50 \pm 0,19$ & $1,00 \pm 0,38$ & $0,88 \pm 0,30$ & $1,25 \pm 0,25$ & $0,38 \pm 0,18$ \\
\hline Tempo levantando (s) & $0,63 \pm 0,26$ & $0,50 \pm 0,19$ & $0,25 \pm 0,25$ & $0,29 \pm 0,29$ & $0,63 \pm 0,18$ & $0,38 \pm 0,18$ & $1,00 \pm 0,38$ & $0,50 \pm 0,33$ & $1,25 \pm 0,31$ & $0,63 \pm 0,32$ \\
\hline Farejos & $3,00 \pm 0,33$ & $2,75 \pm 0,56$ & $2,38 \pm 0,38$ & $0,86 \pm 0,26$ & $1,63 \pm 0,18$ & $2,13 \pm 0,58$ & $4,00 \pm 0,53$ & $2,50 \pm 0,63$ & $5,13 \pm 0,77$ & $4,38 \pm 0,46$ \\
\hline Tempo farejando (s) & $4,38 \pm 0,98$ & $3,88 \pm 0,72$ & $2,38 \pm 0,53$ & $0,57 \pm 0,20$ & $1,38 \pm 0,32$ & $1,75 \pm 0,41$ & $3,38 \pm 0,71$ & $1,75 \pm 0,45$ & $4,75 \pm 0,86$ & $4,13 \pm 0,69$ \\
\hline Limpações & $1,25 \pm 0,37$ & $1,50 \pm 0,27$ & $0,75 \pm 0,37$ & $1,00 \pm 0,65$ & $2,38 \pm 0,86$ & $1,50 \pm 0,53$ & $0,75 \pm 0,31$ & $0,88 \pm 0,30$ & $1,38 \pm 0,26$ & $1,50 \pm 0,57$ \\
\hline Tempo limpando-se (s) & $2,38 \pm 0,86$ & $4,13 \pm 1,29$ & $2,00 \pm 0,85$ & $3,71 \pm 2,25$ & $7,50 \pm 2,24$ & $3,00 \pm 0,96$ & $1,88 \pm 0,97$ & $3,50 \pm 1,35$ & $4,38 \pm 1,43$ & $3,63 \pm 1,35$ \\
\hline \multicolumn{11}{|c|}{ Filhotes testados individualmente } \\
\hline Levantadas & $0,50 \pm 0,34$ & $0,43 \pm 0,30$ & $0,25 \pm 0,16$ & $0,25 \pm 0,16$ & $0,50 \pm 0,19$ & $0,50 \pm 0,19$ & $0,25 \pm 0,16$ & $0,13 \pm 0,13$ & $0,75 \pm 0,16$ & $0,75 \pm 0,37$ \\
\hline Tempo levantando (s) & $0,50 \pm 0,34$ & $0,29 \pm 0,29$ & $0,00 \pm 0,00$ & $0,13 \pm 0,13$ & $0,75 \pm 0,37$ & $0,50 \pm 0,19$ & $0,13 \pm 0,13$ & $0,13 \pm 0,13$ & $0,63 \pm 0,26$ & $0,63 \pm 0,38$ \\
\hline Farejos & $1,83 \pm 0,70$ & $1,86 \pm 0,46$ & $1,50 \pm 0,38$ & $1,25 \pm 0,37$ & $1,63 \pm 0,32$ & $1,63 \pm 0,18$ & $1,00 \pm 0,38$ & $0,88 \pm 0,30$ & $1,13 \pm 0,23$ & $1,88 \pm 0,35$ \\
\hline Tempo farejando (s) & $1,83 \pm 0,91$ & $1,14 \pm 0,34$ & $1,00 \pm 0,46$ & $1,38 \pm 0,32$ & $1,75 \pm 0,62$ & $1,63 \pm 0,32$ & $0,88 \pm 0,30$ & $0,50 \pm 0,27$ & $0,88 \pm 0,30$ & $1,50 \pm 0,50$ \\
\hline Limpações & $0,83 \pm 0,17$ & $1,14 \pm 0,51$ & $0,38 \pm 0,18$ & $0,63 \pm 0,26$ & $0,50 \pm 0,19$ & $0,25 \pm 0,16$ & $0,50 \pm 0,27$ & $0,50 \pm 0,19$ & $1,63 \pm 0,38$ & $1,25 \pm 0,37$ \\
\hline Tempo limpando-se (s) & $2,17 \pm 0,70$ & $3,86 \pm 1,56$ & $2,13 \pm 0,85$ & $3,25 \pm 1,45$ & $1,13 \pm 0,48$ & $0,75 \pm 0,41$ & $0,88 \pm 0,64$ & $0,63 \pm 0,26$ & $6,25 \pm 2,29$ & $3,75 \pm 1,68$ \\
\hline
\end{tabular}


mostrou que nenhum dos grupos foi diferente do seu respectivo controle (filhotes testados com a gaiola vazia) e que os animais testados agrupados levantaram-se por mais tempo do que os testados individualmente.

\subsection{Farejar}

FREQUÊNCIA: A Tabela 1 mostra a frequência de farejos nos cantos do aparato. Uma Anova de três vias mostrou efeitos devidos ao animal presente na gaiola $\left(\mathrm{F}_{[4,133]}=9,681, \mathrm{P}<0,010\right) \mathrm{e}$ ao agrupamento $\left(F_{[1,133]}=51,518, P<0,001\right)$ mas não ao gênero $\left(F_{[1,133]}=1,845, P=0,177\right)$ sobre a frequência de farejar e, assim, os sujeitos foram agrupados de acordo com o animal presente na gaiola e o agrupamento e os dados analisados com uma Anova de duas vias. Esta análise mostrou que houve efeitos gerais do animal presente na gaiola $\left(\mathrm{F}_{[4,143]}=9,007, \mathrm{P}<\right.$ $0,001)$ e do agrupamento $\left(\mathrm{F}_{[1,143]}=52,643, \mathrm{P}<0,001\right)$ sobre a frequência de cheirar nos cantos bem como uma interação entre os fatores $\left(\mathrm{F}_{[4,143]}=8,922, \mathrm{P}<0,001\right)$. O teste de comparações múltiplas de Holm-Sidak indicou que quando comparados com os controles, os animais testados em grupo nas presenças da cobaia, da ama ou da fêmea farejaram mais frequentemente, enquanto não ocorreram diferenças com os animais testados na presença do macho. Quando os animais foram testados individualmente não ocorreram diferenças significativas no comportamento de farejar. Os animais testados agrupados farejaram mais frequentemente que os individuais quando testados com a gaiola vazia ou com o macho ou a cobaia. Os filhotes testados tanto agrupados quanto individuais não diferiram quando testados com a ama ou a fêmea presente na gaiola.

TEMPO: A Tabela 1 mostra o tempo gasto farejando os cantos do campo aberto. Uma Anova de três vias mostrou efeitos gerais devidos ao animal presente na gaiola $\left(\mathrm{F}_{[4,136]}=7,439, \mathrm{P}<\right.$ 0,001) e ao agrupamento $\left(\mathrm{F}_{[1,136]}=44,145, \mathrm{P}<0,001\right)$, mas não ao gênero $\left(\mathrm{F}_{[1,136]}=3,220, \mathrm{P}\right.$ $=0,075)$, sobre o tempo gasto farejando nos cantos. Por isso, agrupamos os sujeitos e analisamos os dados com uma Anova de duas vias, com animal presente na gaiola e agrupamento como fatores. Esta análise mostrou efeitos gerais do animal presente na gaiola $\left(\mathrm{F}_{[4,146]}=7,177, \mathrm{P}<0,001\right)$ e do agrupamento $\left(\mathrm{F}_{[1,146]}=44,663, \mathrm{P}<0,001\right)$ sobre o tempo gasto farejando os cantos. A análise ainda mostrou uma interação entre os fatores $\left(\mathrm{F}_{[4,146]}\right.$ =7,937, $\mathrm{P}<0,001)$. O teste de comparações múltiplas mostrou que os filhotes testados agrupados na presença da cobaia, da ama ou da fêmea na gaiola gastaram mais tempo farejando os cantos do que os controles enquanto os testados na presença do macho não apresentaram diferenças. $\mathrm{O}$ teste mostrou ainda que os filhotes testados individualmente com qualquer dos adultos presentes na gaiola não diferiram significativamente dos controles 
testados com a gaiola vazia. Os animais agrupados farejaram os cantos mais tempo que os testados individualmente quando a gaiola estava vazia ou continha o macho ou a cobaia. Por outro lado, não ocorreram diferenças entre agrupados e individuais quando testados na presença da ama ou da fêmea.

\subsection{Limpar-se}

FREQUÊNCIA: A Tabela 1 mostra a frequência de limpações nos cantos do aparato. Uma Anova de três vias mostrou que houve efeitos devido ao animal presente na gaiola $\left(\mathrm{F}_{[4,136]}=2,682, \mathrm{P}=0,034\right)$ e ao agrupamento $\left(\mathrm{F}_{[1,136]}=10,210, \mathrm{P}=0,002\right)$, mas não ao gênero $\left(F_{[1,136]}=0,219, P=0,641\right)$, sobre a frequência de limpar-se nos cantos. Assim, agrupamos os sujeitos de ambos os sexos e analisamos os dados com uma Anova de duas vias, tendo como fatores o animal presente na gaiola e o agrupamento. Esta análise mostrou que ocorreram efeitos gerais do animal presente na gaiola $\left(\mathrm{F}_{[4,146]}=2,775, \mathrm{P}=0,029\right)$ e do tipo de agrupamento $\left(\mathrm{F}_{[1,146]}=10,300, \mathrm{P}=0,002\right)$ sobre a frequência de limpar-se, ma que não houve interação entre os fatores $\left(\mathrm{F}_{[4,146]}=2,122, \mathrm{P}=0,081\right)$. $\mathrm{O}$ teste de comparações múltiplas mostrou que não ocorreram diferenças entre o grupo testado com a gaiola vazia e os testados com os demais adultos na gaiola. O teste mostrou também que os animais agrupados, em todas as condições, limparam-se mais frequentemente que os testados individualmente. TEMPO: A Tabela 1 mostra o tempo gasto limpando-se nos cantos do campo aberto.Uma Anova de três vias mostrou que os fatores animal presente na gaiola $(\mathrm{F}[4,136]=2,296, \mathrm{P}=$ 0,062), gênero $(F[1,136]=0,0358, P=0,850)$ e agrupamento $(F[1,136]=3,378, P=0,068)$ não provocaram diferenças no tempo gasto limpando-se nos cantos.

\subsection{Esticar-se:}

O comportamento de esticar-se nos cantos não ocorreu durante os testes.

\section{Exploração das áreas de uma parede}

\subsection{Entradas.}

FREQUÊNCIA. A Figura 5 mostra a frequência de entradas nas áreas de uma parede do aparato. Uma Anova de três vias mostrou que ocorreram efeitos devidos ao animal presente na gaiola $\left(\mathrm{F}_{[4,136]}=7,102, \mathrm{P}<0,001\right)$ e ao agrupamento $\left(\mathrm{F}_{[1,136]}=11,168, \mathrm{P}=0,001\right)$, mas não ao gênero $\left(F_{[1,136]}=0,205, P=0,652\right)$, sobre a frequência de entradas nas áreas de uma parede. Assim, ratos machos e fêmeas de cada grupo foram agrupados e os dados submetidos a uma Anova de duas vias. Esta análise mostrou efeitos gerais do animal presente na gaiola $\left(\mathrm{F}_{[4,146]}=7,246\right.$, 
$\mathrm{P}<0,001)$ e do agrupamento $\left(\mathrm{F}_{[1,146]}=11,745, \mathrm{P}<0,001\right)$ sobre a frequência de entradas nos quadrados com uma parede adjacente. Mostrou ainda uma interação entre os fatores $\left(\mathrm{F}_{[4,146]}=\right.$ 4,892, $\mathrm{P}<0,001)$. O teste de comparações múltiplas mostrou que os filhotes testados agrupados com a cobaia na gaiola entraram mais nos cantos de uma parede do que os controles testados com a gaiola vazia, não havendo diferenças entre esses últimos e os demais grupos testados agrupados. Quando os animais foram testados individualmente não se constataram diferenças entre o grupo controle e os demais grupos. O teste indicou ainda que os animais testados agrupados, com o macho ou a cobaia presentes na gaiola, entraram mais frequentemente nos quadrados com uma parede adjacente do que os testados individualmente com esses mesmos animais. Os animais testados agrupados ou individualmente, com a ama ou a fêmea na gaiola, não apresentaram diferenças entre si.

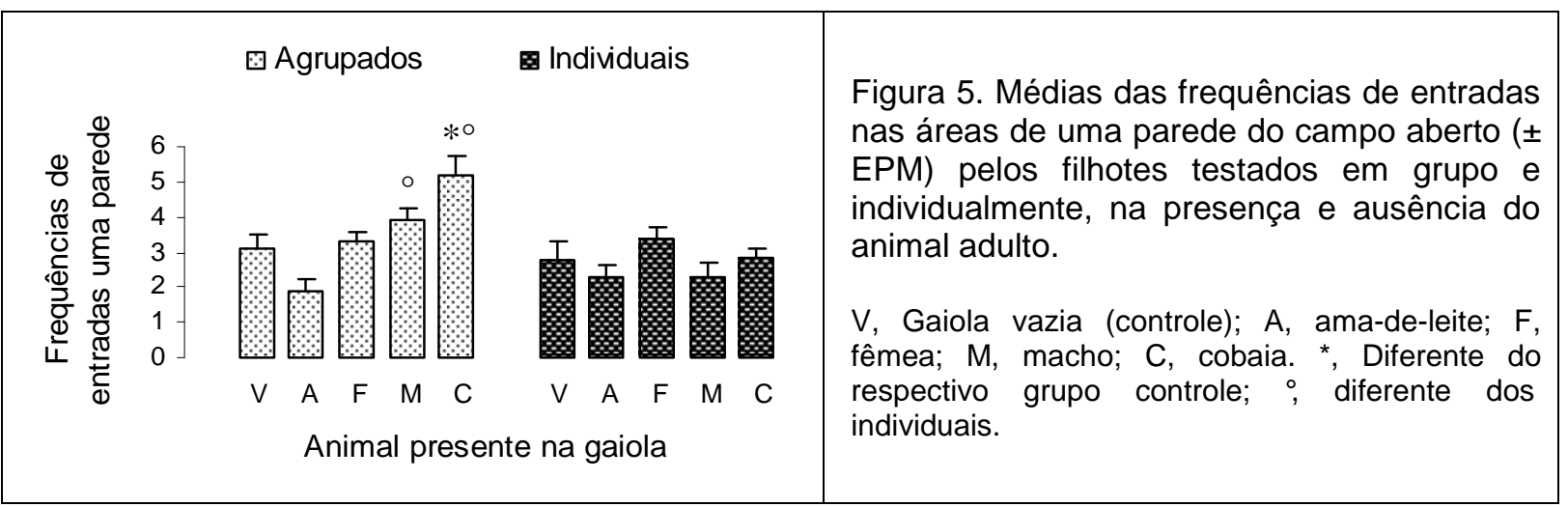

TEMPO: A Figura 6 mostra o tempo gasto nas áreas de uma parede do campo aberto. Uma Anova de três vias mostrou que ocorreram efeitos devidos ao animal presente na gaiola $\left(F_{[4,136]}=2,957, P=0,022\right)$ e ao agrupamento $\left(F_{[1,136]}=5,802, P=0,017\right)$, mas não ao gênero $\left(\mathrm{F}_{[1,136]}=0,027, \mathrm{P}=0,870\right)$, sobre o tempo gasto nos quadrados com uma parede. Por essa razão, os dados foram analisados com uma Anova de duas vias tendo o animal presente na gaiola e o agrupamento como fatores. A análise mostrou efeitos gerais do animal presente na gaiola $\left(\mathrm{F}_{[4,146]}=2,927, \mathrm{P}=0,023\right)$ e do agrupamento $\left(\mathrm{F}_{[1,146]}=6,012, \mathrm{P}=0,015\right)$, além de uma interação entre os fatores $\left(\mathrm{F}_{[1,146]}=2,660, \mathrm{P}=0,035\right)$. $\mathrm{O}$ teste de comparações múltiplas mostrou que os filhotes testados agrupados com a ama na gaiola passaram menos tempo nos quadrados com uma parede do que os testados com a gaiola vazia, enquanto não ocorreram diferenças com os filhotes testados na presença dos demais adultos. Os filhotes testados individualmente, quando comparados com os respectivos controles, não apresentaram diferenças no tempo gasto nesta área. O teste mostrou também que, quando testados com a cobaia na gaiola, os filhotes testados agrupados passaram mais tempo nas áreas com uma 
parede adjacente do que os testados individualmente. Não ocorreram diferenças entre animais testados agrupados ou individualmente com a presença dos demais adultos.

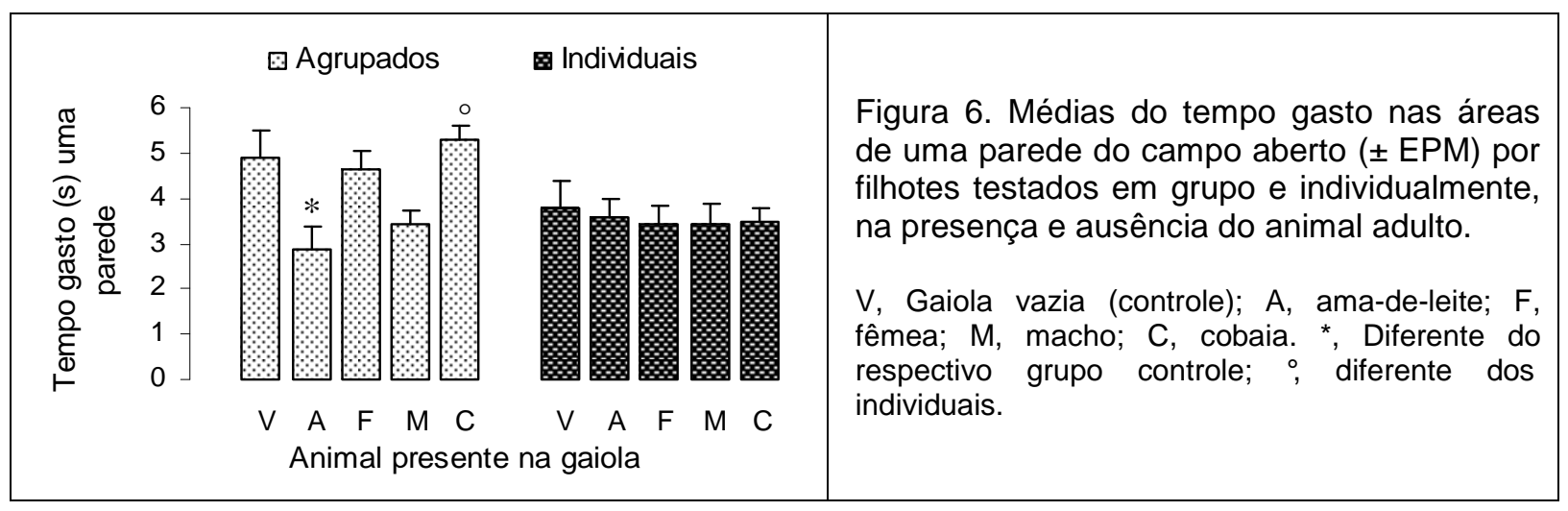

\subsection{Levantar.}

FREQUÊNCIA: A Tabela 2 mostra a frequência de levantadas nas áreas de uma parede do aparato. Uma Anova de três vias mostrou que não houve efeitos devidos ao animal presente na gaiola $\left(\mathrm{F}_{[4,140]}=0,000, \mathrm{P}=1,000\right)$, ao agrupamento $\left(\mathrm{F}_{[1,140]}=0,000, \mathrm{P}=1,000\right)$ nem ao gênero $\left(\mathrm{F}_{[1,140]}=0,000, \mathrm{P}=1,000\right)$, sobre a frequência de levantar-se, e que não houve interação entre os fatores.

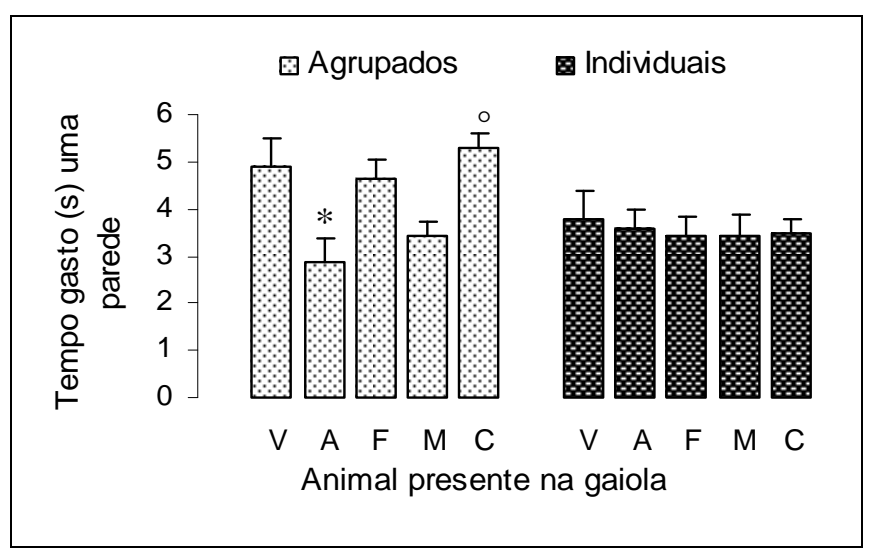

Figura 6. Médias do tempo gasto nas áreas de uma parede do campo aberto ( \pm EPM) por filhotes testados em grupo e individualmente, na presença e ausência do animal adulto.

V, Gaiola vazia (controle); A, ama-de-leite; F, fêmea; M, macho; C, cobaia. *, Diferente do respectivo grupo controle; ; diferente dos individuais.

TEMPO: A Tabela 2 mostra o tempo gasto levantando-se nas áreas de uma parede do campo aberto. Uma Anova de três vias mostrou que não houve efeitos devidos ao animal presente na gaiola $\left(\mathrm{F}_{[4,136]}=0,714, \mathrm{P}=0,583\right)$, ao gênero $\left(\mathrm{F}_{[1,136]}=1,885, \mathrm{P}=0,172\right)$, nem ao agrupamento $(\mathrm{F}[1,136]=1,508, \mathrm{P}=1,000)$, sobre o tempo gasto levantando-se, e também que não houve interação entre os fatores.

\subsection{Farejar.}

FREQUÊNCIA: A Tabela 2 mostra a frequência de farejos nas áreas de uma parede do aparato. Uma Anova de três vias mostrou que não houve efeitos devidos ao animal presente 
Tabela 2 - Comportamentos de filhotes de rato, fêmeas e machos, nos quadrados de uma parede do campo aberto, na presença e ausência de animais adultos na gaiola.

Os dados representam a média individual da ocupação dos quadrados de uma parede e são apresentados como média \pm E. P. M.

\begin{tabular}{|c|c|c|c|c|c|c|c|c|c|c|}
\hline \multirow[b]{3}{*}{ Comportamentos } & \multicolumn{10}{|c|}{ Animal presente na gaiola durante o teste } \\
\hline & \multicolumn{2}{|c|}{ Vazia } & \multicolumn{2}{|c|}{ Ama } & \multicolumn{2}{|c|}{ Fêmea } & \multicolumn{2}{|c|}{ Macho } & \multicolumn{2}{|c|}{ Cobaia } \\
\hline & Fêmeas & Machos & Fêmeas & Machos & Fêmeas & Machos & Fêmeas & Machos & Fêmeas & Machos \\
\hline \multicolumn{11}{|c|}{ Filhotes testados agrupados } \\
\hline Levantadas & $0,00 \pm 0,00$ & $0,00 \pm 0,00$ & $0,00 \pm 0,00$ & $0,00 \pm 0,00$ & $0,00 \pm 0,00$ & $0,00 \pm 0,00$ & $0,00 \pm 0,00$ & $0,00 \pm 0,00$ & $0,00 \pm 0,00$ & $0,00 \pm 0,00$ \\
\hline Tempo levantando (s) & $0,00 \pm 0,00$ & $0,00 \pm 0,00$ & $0,00 \pm 0,00$ & $0,00 \pm 0,00$ & $0,00 \pm 0,00$ & $0,00 \pm 0,00$ & $0,00 \pm 0,00$ & $0,13 \pm 0,13$ & $0,00 \pm 0,00$ & $0,00 \pm 0,00$ \\
\hline Farejos & $0,00 \pm 0,00$ & $0,00 \pm 0,00$ & $0,13 \pm 0,13$ & $0,00 \pm 0,00$ & $0,00 \pm 0,00$ & $0,00 \pm 0,00$ & $0,13 \pm 0,13$ & $0,00 \pm 0,00$ & $0,25 \pm 0,16$ & $0,13 \pm 0,13$ \\
\hline Tempo farejando (s) & $1,00 \pm 0,19$ & $0,88 \pm 0,30$ & $1,88 \pm 0,44$ & $0,86 \pm 0,46$ & $1,00 \pm 0,19$ & $1,50 \pm 0,27$ & $3,25 \pm 0,31$ & $3,00 \pm 0,65$ & $2,25 \pm 0,37$ & $2,13 \pm 0,23$ \\
\hline Limpações & $0,00 \pm 0,00$ & $0,13 \pm 0,13$ & $0,00 \pm 0,00$ & $0,00 \pm 0,00$ & $0,00 \pm 0,00$ & $0,13 \pm 0,13$ & $0,00 \pm 0,00$ & $0,00 \pm 0,00$ & $0,00 \pm 0,00$ & $0,00 \pm 0,00$ \\
\hline Tempo limpando-se (s) & $0,13 \pm 0,13$ & $0,63 \pm 0,32$ & $0,13 \pm 0,13$ & $0,14 \pm 0,14$ & $0,38 \pm 0,18$ & $0,63 \pm 0,38$ & $0,13 \pm 0,13$ & $0,00 \pm 0,00$ & $0,13 \pm 0,13$ & $0,00 \pm 0,00$ \\
\hline \multicolumn{11}{|c|}{ Filhotes testados individualmente } \\
\hline Levantadas & $0,00 \pm 0,00$ & $0,00 \pm 0,00$ & $0,00 \pm 0,00$ & $0,00 \pm 0,00$ & $0,00 \pm 0,00$ & $0,00 \pm 0,00$ & $0,00 \pm 0,00$ & $0,00 \pm 0,00$ & $0,00 \pm 0,00$ & $0,00 \pm 0,00$ \\
\hline Tempo levantando (s) & $0,00 \pm 0,00$ & $0,00 \pm 0,00$ & $0,00 \pm 0,00$ & $0,00 \pm 0,00$ & $0,00 \pm 0,00$ & $0,13 \pm 0,13$ & $0,00 \pm 0,00$ & $0,00 \pm 0,00$ & $0,00 \pm 0,00$ & $0,00 \pm 0,00$ \\
\hline Farejos & $0,17 \pm 0,17$ & $0,00 \pm 0,00$ & $0,00 \pm 0,00$ & $0,00 \pm 0,00$ & $0,00 \pm 0,00$ & $0,00 \pm 0,00$ & $0,00 \pm 0,00$ & $0,00 \pm 0,00$ & $0,00 \pm 0,00$ & $0,00 \pm 0,00$ \\
\hline Tempo farejando (s) & $1,00 \pm 0,52$ & $1,29 \pm 0,36$ & $1,25 \pm 0,49$ & $1,75 \pm 0,25$ & $1,38 \pm 0,32$ & $2,00 \pm 0,27$ & $1,75 \pm 0,25$ & $1,75 \pm 0,37$ & $1,00 \pm 0,19$ & $1,00 \pm 0,38$ \\
\hline Limpações & $0,00 \pm 0,00$ & $0,00 \pm 0,00$ & $0,00 \pm 0,00$ & $0,00 \pm 0,00$ & $0,00 \pm 0,00$ & $0,00 \pm 0,00$ & $0,00 \pm 0,00$ & $0,00 \pm 0,00$ & $0,00 \pm 0,00$ & $0,00 \pm 0,00$ \\
\hline Tempo limpando-se (s) & $0,17 \pm 0,17$ & $0,00 \pm 0,00$ & $0,00 \pm 0,00$ & $0,00 \pm 0,00$ & $0,00 \pm 0,00$ & $0,13 \pm 0,13$ & $0,00 \pm 0,00$ & $0,00 \pm 0,00$ & $0,00 \pm 0,00$ & $0,13 \pm 0,13$ \\
\hline
\end{tabular}


na gaiola $\left(\mathrm{F}_{[4,136]}=1,018, \mathrm{P}=0,400\right)$, ao agrupamento $\left(\mathrm{F}_{[1,136]}=2,236, \mathrm{P}=0,137\right)$ nem ao gênero $\left(\mathrm{F}_{[1,136]}=3,122, \mathrm{P}=0,079\right)$, sobre a frequência de farejar. Além disso, não houve interação entre os fatores.

TEMPO: A Tabela 2 mostra o tempo gasto farejando as áreas de uma parede do campo aberto. Uma Anova de três vias mostrou efeitos gerais devidos ao animal presente na gaiola $\left(\mathrm{F}_{[4,136]}=8,338, \mathrm{P}<0,001\right)$ e ao agrupamento $\left(\mathrm{F}_{[1,136]}=5,031, \mathrm{P}<0,027\right)$, mas não ao gênero $\left(\mathrm{F}_{[1,136]}=0,061, \mathrm{P}=0,805\right)$, sobre o tempo gasto farejando nos quadrados de uma parede. Ainda, houve interação entre os fatores $\left(\mathrm{F}_{[4,136]}=5,838, \mathrm{P}<0,001\right)$. Por isso, os sujeitos foram agrupados e os dados analisados com uma Anova de duas vias, tendo como fatores o animal presente na gaiola e o agrupamento. Essa análise mostrou efeitos gerais do animal presente na gaiola $\left(\mathrm{F}_{[4,146]}=8,359, \mathrm{P}<0,001\right)$ e do agrupamento $\left(\mathrm{F}_{[1,146]}=5,231, \mathrm{P}=0,024\right)$ sobre o tempo gasto farejando os quadrados adjacentes a uma parede. Mostrou ainda interação entre os fatores $\left(\mathrm{F}_{[4,146]}=5,871, \mathrm{P}<0,001\right)$. O teste de comparações múltiplas mostrou que os filhotes testados agrupados na presença do macho ou da cobaia na gaiola gastaram mais tempo farejando os quadrados de uma parede do que os testados com a gaiola vazia, enquanto os testados na presença da ama ou da fêmea não apresentaram diferenças. O teste mostrou ainda que quando testados individualmente com qualquer dos adultos presentes na gaiola, os filhotes não diferiram significativamente dos controles testados com a gaiola vazia. Os animais agrupados farejaram os quadrados adjacentes a uma parede mais tempo que os testados individualmente quando a gaiola continha o macho ou a cobaia. Por outro lado, não ocorreram diferenças entre agrupados e individuais quando testados na presença da ama, da fêmea ou com a gaiola vazia.

\subsection{Limpar-se.}

FREQUÊNCIA: A Tabela 2 mostra a frequência de limpações nas áreas de uma parede do aparato. Uma Anova de três vias mostrou que não houve efeitos devidos ao animal presente na gaiola $\left(\mathrm{F}_{[4,136]}=0,702, \mathrm{P}=0,592\right)$, ao agrupamento $\left(\mathrm{F}_{[1,136]}=1,885, \mathrm{P}=0,172\right)$ nem ao gênero $\left(\mathrm{F}_{[1,136]}=1,885, \mathrm{P}=0,172\right)$, sobre a frequência de limpar-se. Além disso, não houve interação entre os fatores.

TEMPO: A Tabela 2 mostra o tempo gasto limpando-se nas áreas de uma parede do campo aberto. Uma Anova de três vias mostrou efeitos gerais apenas devidos ao agrupamento $(\mathrm{F}[1,136]=8,013, \mathrm{P}=0,005)$, e não ao animal presente na gaiola $(\mathrm{F}[4,136]=2,400, \mathrm{P}=$ $0,053)$ ou ao gênero $(F[1,136]=0,845, P=0,360)$. Os dados foram agrupados e uma Anova de uma via mostrou efeitos gerais devidos ao agrupamento $(\mathrm{F}[1,154]=8,000, \mathrm{P}=0,005)$ 
enquanto o teste de comparações múltiplas indicou que os animais testados em grupo se limparam por mais tempo que os testados individualmente nas áreas adjacentes a uma parede.

\subsection{Esticar-se.}

O comportamento de esticar-se nas áreas de uma parede não ocorreu durante os testes.

\section{Exploração do quadrado em frente à gaiola}

\subsection{Entradas}

FREQUÊNCIA. A Figura 7 mostra a frequência de entradas na área da gaiola. Uma Anova de três vias mostrou que ocorreram efeitos apenas devidos ao animal presente na gaiola $\left(\mathrm{F}_{[4,136]}=11,031, \mathrm{P}<0,001\right)$, mas não ao agrupamento $\left(\mathrm{F}_{[1,136]}=0,805, \mathrm{P}=0,371\right)$ ou ao gênero $\left(\mathrm{F}_{[1,136]}=0,0008, \mathrm{P}=0,977\right)$, sobre a frequência de entradas no quadrado em frente à gaiola. Mostrou também que houve interação entre os fatores animal presente na gaiola e agrupamento $\left(\mathrm{F}_{[4,136]}=4,380, \mathrm{P}=0,002\right)$. Assim, os animais foram reagrupados e uma Anova de duas vias foi realizada tendo como fatores animal presente na gaiola e agrupamento. $\mathrm{O}$ teste mostrou efeitos gerais do animal presente na gaiola $\left(\mathrm{F}_{[4,146]}=11,017, \mathrm{P}<0,001\right)$, mas não do agrupamento $\left(\mathrm{F}_{[4,146]}=0,763, \mathrm{P}=0,384\right)$, mostrando ainda a ocorrência de interação entre os fatores $\left(\mathrm{F}_{[4,146]}=4,360, \mathrm{P}=0,002\right)$.

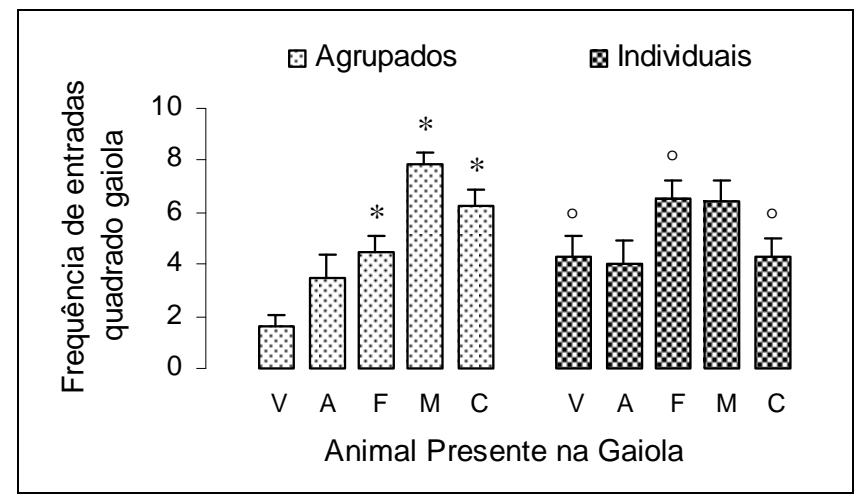

Figura 7. Médias das frequências de entradas no quadrado em frente da gaiola ( \pm EPM) pelos filhotes testados em grupo e individualmente, na presença e ausência do animal adulto.

V, Gaiola vazia (controle); A, ama-de-leite; F, fêmea; M, macho; C, cobaia. *, Diferente do grupo controle; ', diferente dos agrupados.

O teste de comparações múltiplas indicou que os animais testados agrupados na presença do macho, ou da fêmea ou da cobaia na gaiola, quando comparados com os animais controle, entraram mais frequentemente no quadrado em frente à gaiola. Já os animais testados agrupados na presença da ama não diferiram dos agrupados testados com a gaiola vazia. Os filhotes testados individualmente não apresentaram diferenças quando comparados aos controles testados com a gaiola vazia. O teste indicou ainda que os filhotes testados individualmente com a gaiola vazia, com a fêmea ou a cobaia entraram mais frequentemente no quadrado em frente a gaiola do que os filhotes testados em grupo. Não houve diferenças 
significativas entre os animais testados em grupo e os individuais quando estavam na presença da ama ou do macho.

TEMPO: A Figura 8 mostra o tempo gasto no quadrado em frente à gaiola. Uma Anova de três vias mostrou efeitos gerais devidos ao animal presente na gaiola $\left(\mathrm{F}_{[4,136]}=24,207, \mathrm{P}<\right.$ $0,001)$ e ao agrupamento $\left(\mathrm{F}_{[1,136]}=15,577, \mathrm{P}<0,001\right)$, mas não devidos ao gênero $\left(\mathrm{F}_{[1,136]}=\right.$ $0,779, \mathrm{P}=0,379)$ sobre o tempo gasto no quadrado em frente a gaiola. Por essa razão, fêmeas e machos foram agrupados e os resultados submetidos a uma Anova de duas vias. Essa análise mostrou que houve efeitos do animal presente na gaiola $\left(\mathrm{F}_{[4,146]}=24,904, \mathrm{P}<0,001\right)$ e do agrupamento $\left(\mathrm{F}_{[1,146]}=16,126, \mathrm{P}<0,001\right)$ sobre o tempo gasto em frente ao quadrado da gaiola, e mostrou ainda que não houve interação entre os fatores. O teste de comparações múltiplas indicou que os animais testados na presença do macho, da fêmea ou da ama na gaiola, passaram mais tempo no quadrado em frente a gaiola do que os filhotes do grupo testado com a gaiola vazia. Estes últimos, por sua vez, não diferiram dos filhotes testados na presença da cobaia na gaiola. $\mathrm{O}$ teste mostrou ainda que os filhotes testados individualmente passaram mais tempo em frente a gaiola que os animais testados agrupados.

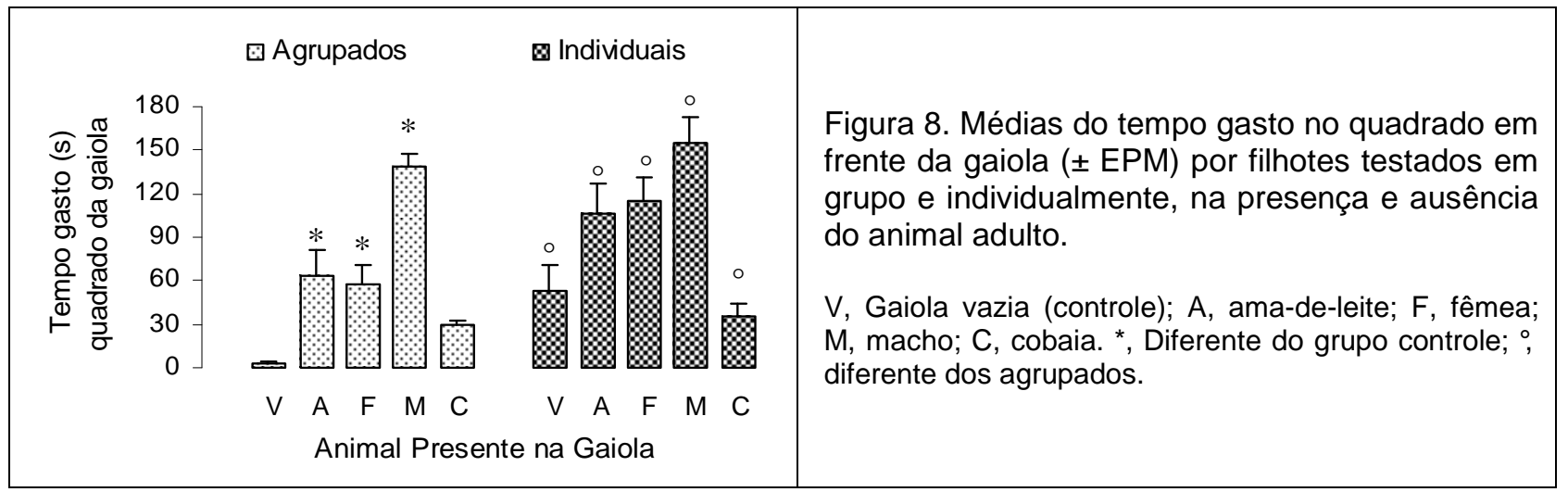

\subsection{Levantar.}

FREQUÊNCIA: A Tabela 3 mostra a frequência de levantadas em frente à gaiola. Uma Anova de três vias mostrou efeitos gerais do animal presente na gaiola $\left(\mathrm{F}_{[4,136]}=8,167, \mathrm{P}<\right.$ $0,001)$, mas não do agrupamento $\left(F_{[1,136]}=1,291, P=0,258\right)$ e do gênero $\left(F_{[1,136]}=0,236, P=\right.$ 0,628 ), sobre a frequência de levantar-se em frente a gaiola, e também que não houve interação entre os fatores. Os animais foram reagrupados e uma anova de uma via foi feita tendo animal presente na gaiola como fator único. Essa análise mostrou efeitos gerais do animal presente na gaiola $\left(\mathrm{F}_{[4,151]}=8,498, \mathrm{P}<0,001\right)$ sobre a frequência de levantar-se. $\mathrm{O}$ teste de comparações múltiplas de Holm-Sidak indicou que na presença da ama, do macho ou da fêmea, os animais levantaram-se com mais frequência no quadrado em frente a gaiola do 
que os do grupo controle, testados com a gaiola vazia. Na presença da cobaia na gaiola, os animais testados não apresentaram diferenças com os controles.

TEMPO: A Tabela 3 mostra o tempo gasto levantando-se no quadrado em frente à gaiola. Uma Anova de três vias mostrou efeitos apenas para o fator animal presente na gaiola $\left(\mathrm{F}_{[4,136]}=6,934, \mathrm{P}<0,001\right)$, mas não para agrupamento $\left(\mathrm{F}_{[1,136]}=0,296, \mathrm{P}=0,587\right)$ e gênero $\left(\mathrm{F}_{[1,136]}=0,045, \mathrm{P}=0,832\right)$, sobre o tempo gasto levantando-se, mostrando ainda que não houve interação entre os fatores. Os animais foram reagrupados e uma Anova de uma via foi feita tendo animal presente na gaiola como único fator. Essa análise mostrou que o animal presente na gaiola $\left(\mathrm{F}_{[4,151]}=7,386, \mathrm{P}<0,001\right)$ influenciou o tempo gasto levantando-se na frente da gaiola. O teste de comparações múltiplas indicou que, na presença da ama, do macho ou da fêmea, os animais passaram mais tempo levantando-se no quadrado em frente da gaiola do que os animais do grupo controle. Na presença da cobaia na gaiola os animais testados não apresentaram diferenças em relação aos testados com a gaiola vazia.

\subsection{Farejar.}

FREQUÊNCIA: A Tabela 3 mostra a frequência de farejos em frente à gaiola. Uma Anova de três vias mostrou efeitos apenas devidos ao animal presente na gaiola $\left(\mathrm{F}_{[4,136]}=\right.$ $18,137, \mathrm{P}<0,001)$ e não para agrupamento $\left(\mathrm{F}_{[1,136]}=1,964, \mathrm{P}=0,163\right)$ e gênero $\left(\mathrm{F}_{[1,136]}=\right.$ $0,632, \mathrm{P}=0,428$ ) sobre a frequência de farejar. Mostrou ainda interação entre o animal presente na gaiola e o agrupamento $\left(\mathrm{F}_{[4,136]}=4,310, \mathrm{P}=0,003\right)$. Assim, os sujeitos foram reagrupados e os dados analisados com uma Anova de duas vias, tendo como fatores o animal presente na gaiola e o agrupamento. Essa análise mostrou efeitos gerais do animal

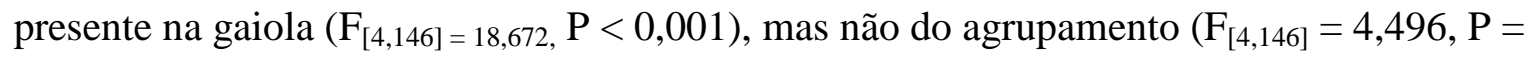
0,002) sobre a frequência de farejar em frente a gaiola. Mostrou ainda uma interação entre os fatores $\left(\mathrm{F}_{[4,146]}=4,496, \mathrm{P}=0,002\right)$. O teste de comparações múltiplas indicou que os animais testados agrupados na presença da ama, da fêmea ou do macho farejaram mais que os animais testados com a gaiola vazia. Na presença da cobaia este comportamento dos filhotes não diferiu dos filhotes testados com a gaiola vazia. Com o macho presente na gaiola, os animais testados individualmente farejaram mais frequentemente no quadrado em frente da gaiola do que os testados com a gaiola vazia. Na presença dos demais adultos, os filhotes testados individualmente não apresentaram diferenças dos animais controle. Com a gaiola vazia ou na presença do macho ou da fêmea, os filhotes testados em grupo farejaram menos frequentemente o quadrado em frente da gaiola do que os filhotes testados individualmente. 
Na presença da ama ou da cobaia, tanto os filhotes testados em grupo como os testados individualmente não apresentaram diferenças no comportamento de farejar.

TEMPO: A Tabela 3 mostra o tempo gasto farejando em frente à gaiola. Uma Anova de três vias mostrou somente efeitos gerais devidos ao animal presente na gaiola $\left(\mathrm{F}_{[4,136]}=\right.$ $16,098, \mathrm{P}<0,001)$, e não ao agrupamento $\left(\mathrm{F}_{[1,136]}=0,560, \mathrm{P}=0,455\right)$ ou ao gênero $\left(\mathrm{F}_{[1,136]}\right.$ $=0,214, \mathrm{P}=0,644)$, sobre o tempo gasto farejando no quadrado em frente da gaiola. Mostrou ainda uma interação entre os fatores animal presente na gaiola e agrupamento $\left(\mathrm{F}_{[4,136]}=3,104\right.$, $\mathrm{P}=0,018$ ). Assim, os filhotes foram reagrupados e os dados analisados com uma Anova de duas vias, tendo como fatores o animal presente na gaiola e o agrupamento. Essa análise mostrou efeitos gerais do animal presente na gaiola $\left(\mathrm{F}_{[4,146]}=16,721, \mathrm{P}<0,001\right)$, mas não do agrupamento $\left(\mathrm{F}_{[4,146]}=3,233, \mathrm{P}=0,014\right)$, sobre o tempo gasto farejando o quadrado em frente da gaiola. Também mostrou uma interação entre os fatores $\left(\mathrm{F}_{[4,146]}=3,233, \mathrm{P}=0,014\right)$. $\mathrm{O}$ teste de comparações múltiplas indicou que os animais testados agrupados na presença da ama, da fêmea ou do macho passaram mais tempo farejando o quadrado em frente a gaiola que os animais do grupo controle, testados com a gaiola vazia. Ainda, os animais testados agrupados na presença da cobaia não apresentaram diferenças quando comparados com os animais testados com a gaiola vazia. Resultado análogo foi encontrado no caso dos animais testados individualmente. Os filhotes testados individualmente na presença da fêmea ou do macho farejaram por mais tempo que os animais testados em grupo. Os animais testados na presença da ama ou da cobaia, agrupados ou individualmente, não apresentaram diferenças nesse comportamento.

\subsection{Limpar-se.}

FREQUÊNCIA: A Tabela 3 mostra a frequência de limpações em frente à gaiola. Uma Anova de três vias mostrou que houve efeitos gerais devidos ao animal presente na gaiola $\left(F_{[4,136]}=2,658, P=0,035\right)$ e ao gênero $\left(F_{[1,136]}=4,174, P=0,043\right)$, mas não devidos ao agrupamento $\left(\mathrm{F}_{[1,136]}=0,219, \mathrm{P}=0,641\right)$, sobre a frequência de limpar-se no quadrado em frente da gaiola. Mostrou ainda que não houve interação entre os fatores. Desta forma, os animais foram reagrupados e os dados analisados com uma Anova de duas vias, tendo como fatores o animal presente na gaiola e o gênero. Essa análise mostrou efeitos gerais do animal presente na gaiola $(\mathrm{F}[4,146]=2,835, \mathrm{P}=0,027)$ e do gênero $(\mathrm{F}[1,146]=4,324, \mathrm{P}=0,039)$ sobre a frequência de limpar-se, e que não houve interação entre os fatores $(\mathrm{F}[4,146]=0,354$, $\mathrm{P}=0,841)$. O teste de comparações múltiplas mostrou que na presença do macho na gaiola, os animais limparam-se com mais frequência em frente a gaiola do que os testados com a gaiola 
Tabela 3 - Comportamentos de filhotes de rato, fêmeas e machos, no quadrado em frente à gaiola que continha animais adultos ou ficava vazia.

Os dados representam a média individual da ocupação desta área e são apresentados como média \pm E. P. M.

\begin{tabular}{|c|c|c|c|c|c|c|c|c|c|c|}
\hline \multirow[b]{3}{*}{ Comportamentos } & \multicolumn{10}{|c|}{ Animal presente na gaiola durante o teste } \\
\hline & \multicolumn{2}{|c|}{ Vazia } & \multicolumn{2}{|c|}{ Ama } & \multicolumn{2}{|c|}{ Fêmea } & \multicolumn{2}{|c|}{ Macho } & \multicolumn{2}{|c|}{ Cobaia } \\
\hline & Fêmeas & Machos & Fêmeas & Machos & Fêmeas & Machos & Fêmeas & Machos & Fêmeas & Machos \\
\hline \multicolumn{11}{|c|}{ Filhotes testados agrupados } \\
\hline Levantadas & $0,13 \pm 0,13$ & $0,00 \pm 0,00$ & $3,00 \pm 1,02$ & $2,71 \pm 1,70$ & $2,38 \pm 1,12$ & $1,38 \pm 0,56$ & $5,00 \pm 1,64$ & $4,13 \pm 1,37$ & $0,25 \pm 0,16$ & $1,50 \pm 0,50$ \\
\hline Tempo levantando (s) & $0,00 \pm 0,00$ & $0,00 \pm 0,00$ & $10,00 \pm 3,67$ & $11,14 \pm 6,27$ & $6,00 \pm 3,27$ & $2,63 \pm 1,22$ & $11,00 \pm 4,62$ & $9,13 \pm 3,59$ & $0,88 \pm 0,64$ & $2,63 \pm 1,03$ \\
\hline Farejos & $0,25 \pm 0,16$ & $0,25 \pm 0,16$ & $8,63 \pm 2,43$ & $5,86 \pm 3,28$ & $4,00 \pm 1,77$ & $5,38 \pm 1,24$ & $18,38 \pm 1,88$ & $19,00 \pm 4,98$ & $5,75 \pm 1,87$ & $4,88 \pm 0,85$ \\
\hline Tempo farejando (s) & $0,13 \pm 0,13$ & $0,13 \pm 0,13$ & $33,88 \pm 8,98$ & $25,00 \pm 13,92$ & $22,00 \pm 10,63$ & $15,75 \pm 6,12$ & $59,38 \pm 8,38$ & $43,75 \pm 7,34$ & $8,63 \pm 2,58$ & $7,38 \pm 1,57$ \\
\hline Limpações & $0,00 \pm 0,00$ & $0,00 \pm 0,00$ & $0,13 \pm 0,13$ & $0,14 \pm 0,14$ & $0,25 \pm 0,16$ & $0,63 \pm 0,26$ & $0,63 \pm 0,50$ & $0,88 \pm 0,74$ & $0,13 \pm 0,13$ & $0,13 \pm 0,13$ \\
\hline Tempo limpando-se (s) & $0,00 \pm 0,00$ & $0,00 \pm 0,00$ & $0,10 \pm 0,10$ & $0,06 \pm 0,06$ & $1,08 \pm 0,89$ & $2,63 \pm 2,02$ & $2,58 \pm 2,38$ & $3,14 \pm 2,05$ & $0,03 \pm 0,03$ & $0,92 \pm 0,92$ \\
\hline Subidas na grade & $0,00 \pm 0,00$ & $0,00 \pm 0,00$ & $1,50 \pm 0,53$ & $0,43 \pm 0,30$ & $0,63 \pm 0,42$ & $0,38 \pm 0,18$ & $2,38 \pm 0,63$ & $0,50 \pm 0,33$ & $0,00 \pm 0,00$ & $0,00 \pm 0,00$ \\
\hline Tempo subindo na grade (s) & $0,00 \pm 0,00$ & $0,00 \pm 0,00$ & $6,00 \pm 2,37$ & $1,71 \pm 1,29$ & $2,50 \pm 1,68$ & $0,63 \pm 0,32$ & $13,13 \pm 5,32$ & $1,88 \pm 1,32$ & $0,00 \pm 0,00$ & $0,00 \pm 0,00$ \\
\hline \multicolumn{11}{|c|}{ Filhotes testados individualmente } \\
\hline Levantadas & $0,33 \pm 0,21$ & $2,29 \pm 1,02$ & $3,00 \pm 1,48$ & $3,38 \pm 0,73$ & $2,50 \pm 0,87$ & $4,13 \pm 0,81$ & $3,50 \pm 0,89$ & $3,25 \pm 0,70$ & $1,75 \pm 0,49$ & $1,13 \pm 0,79$ \\
\hline Tempo levantando (s) & $0,83 \pm 0,65$ & $3,29 \pm 1,77$ & $10,25 \pm 6,86$ & $9,38 \pm 2,90$ & $5,75 \pm 2,02$ & $12,25 \pm 3,73$ & $8,88 \pm 3,63$ & $6,75 \pm 1,31$ & $2,13 \pm 0,69$ & $1,50 \pm 1,36$ \\
\hline Farejos & $4,00 \pm 2,54$ & $7,00 \pm 1,88$ & $7,13 \pm 2,95$ & $11,38 \pm 2,56$ & $9,00 \pm 2,51$ & $12,75 \pm 1,96$ & $14,00 \pm 2,46$ & $12,13 \pm 2,25$ & $4,38 \pm 1,10$ & $5,13 \pm 2,45$ \\
\hline Tempo farejando (s) & $6,67 \pm 4,08$ & $11,86 \pm 4,26$ & $29,25 \pm 15,15$ & $36,50 \pm 10,39$ & $33,38 \pm 9,99$ & $43,25 \pm 8,96$ & $36,25 \pm 9,72$ & $30,13 \pm 6,66$ & $8,13 \pm 2,14$ & $7,38 \pm 3,50$ \\
\hline Limpações & $0,00 \pm 0,00$ & $0,57 \pm 0,57$ & $0,13 \pm 0,13$ & $0,25 \pm 0,16$ & $0,00 \pm 0,00$ & $0,75 \pm 0,41$ & $0,50 \pm 0,27$ & $1,00 \pm 0,60$ & $0,00 \pm 0,00$ & $0,38 \pm 0,38$ \\
\hline Tempo limpando-se (s) & $0,00 \pm 0,00$ & $2,26 \pm 2,26$ & $1,03 \pm 1,03$ & $2,62 \pm 2,05$ & $0,00 \pm 0,00$ & $2,34 \pm 1,22$ & $1,37 \pm 0,71$ & $2,99 \pm 1,50$ & $0,00 \pm 0,00$ & $0,31 \pm 0,31$ \\
\hline Subidas na grade & $0,00 \pm 0,00$ & $0,00 \pm 0,00$ & $1,00 \pm 0,76$ & $0,50 \pm 0,38$ & $1,63 \pm 0,60$ & $1,00 \pm 0,42$ & $0,63 \pm 0,32$ & $0,00 \pm 0,00$ & $0,13 \pm 0,13$ & $0,13 \pm 0,13$ \\
\hline Tempo subindo na grade (s) & $0,00 \pm 0,00$ & $0,00 \pm 0,00$ & $2,88 \pm 1,88$ & $3,00 \pm 1,97$ & $9,75 \pm 4,08$ & $5,00 \pm 2,40$ & $2,75 \pm 1,40$ & $0,00 \pm 0,00$ & $0,13 \pm 0,13$ & $0,13 \pm 0,13$ \\
\hline
\end{tabular}


vazia. Os animais testados na presença da ama, da fêmea ou da cobaia não apresentaram diferenças quando comparados com o grupo controle. O teste mostrou também que os machos limparam-se com mais frequência em frente ao quadrado da gaiola que as fêmeas.

TEMPO: A Tabela 3 mostra o tempo gasto limpando-se em frente à gaiola. Uma Anova de três vias mostrou efeitos gerais do gênero $(\mathrm{F}[1,136]=3,916, \mathrm{P}=0,050)$, mas não do animal presente na gaiola $(\mathrm{F}[4,136]=2,062, \mathrm{P}=0,089)$ e nem do agrupamento $(\mathrm{F}[1,136]=$ $0,233, \mathrm{P}=0,630)$ sobre o tempo gasto limpando-se em frente a gaiola. Também mostrou que não houve interação entre os fatores. Desta forma, os filhotes foram reagrupados e os dados analisados com uma Anova de uma via, que evidenciou um efeito do gênero $(\mathrm{F}[1,154]=$ $4,030, \mathrm{P}=0,046)$ sobre o tempo gasto limpando-se em frente à gaiola. $\mathrm{O}$ teste de comparações múltiplas indicou os machos passaram mais tempo limpando-se em frente a gaiola do que as fêmeas.

\subsection{Subir na grade.}

FREQUÊNCIA: A Tabela 3 mostra a frequência com que os animais subiram na grade da gaiola. Uma Anova de três vias mostrou efeitos devidos ao animal presente na gaiola $\left(\mathrm{F}_{[4,136]}=6,612, \mathrm{P}<0,001\right)$ e ao gênero $\left(\mathrm{F}_{[1,136]}=9,435, \mathrm{P}=0,003\right)$, mas não ao agrupamento $\left(F_{[1,136]}=0,249, P=0,619\right)$. Mostrou ainda uma interação entre os fatores animal presente na gaiola e agrupamento $\left(\mathrm{F}_{[4,136]}=3,883, \mathrm{P}=0,005\right)$. O teste de comparações múltiplas mostrou que

as fêmeas subiram mais frequentemente na grade da gaiola do que os machos quando a gaiola estava vazia, e não diferiram dos machos quando na gaiola estavam a ama, a fêmea, o macho ou a cobaia. As fêmeas testadas em grupo subiram mais frequentemente na grade da gaiola do que as fêmeas testadas individualmente, uma diferença não observada nos machos. Em comparação com os machos, as fêmeas não foram diferentes nas mesmas circunstâncias de agrupamento, testados individualmente ou agrupados. Os animais testados agrupados com a gaiola vazia, com a ama e o macho subiram mais frequentemente na grade do que os testados individualmente. Na presença da fêmea ou da cobaia na gaiola, os filhotes não apresentaram diferenças no comportamento devidos ao agrupamento.

TEMPO: A Tabela 3 mostra o tempo gasto pelos animais subindo na grade da gaiola. Uma Anova de três vias mostrou efeitos gerais devidos ao animal presente na gaiola $\left(\mathrm{F}_{[4,136]}=\right.$ $5,404, \mathrm{P}<0,001)$ e ao gênero $\left(\mathrm{F}_{[1,136]}=8,078, \mathrm{P}=0,005\right)$, mas não ao agrupamento $\left(\mathrm{F}_{[1,136]}=\right.$ $0,0645, P=0,800)$. Mostrou também uma interação entre os fatores animal presente na gaiola e agrupamento $\left(\mathrm{F}_{[4,136]}=4,873, \mathrm{P}=0,001\right)$. $\mathrm{O}$ teste de comparações múltiplas mostrou que as 
fêmeas passaram mais tempo subindo na grade da gaiola do que os machos quando a gaiola estava vazia. As fêmeas não se comportaram diferentemente dos machos quando estavam presentes na gaiola a ama, a fêmea, o macho ou a cobaia. As fêmeas testadas em grupo passaram mais tempo subindo na grade da gaiola do que as fêmeas testadas individualmente enquanto os machos não apresentaram diferenças. Não ocorreram diferenças significativas no comportamento das fêmeas quando comparadas com os machos, seja testados individualmente seja testados agrupados. Os animais testados agrupados com a gaiola vazia ou com a ama passaram mais tempo subindo na grade do que os testados individualmente. Com a fêmea, o macho ou a cobaia presentes na gaiola, os filhotes, tanto testados individualmente como agrupados, não apresentaram diferenças.

\subsection{Esticar-se.}

O comportamento de esticar-se em frente à gaiola não ocorreu durante os testes.

\section{Exploração do centro}

\subsection{Entradas}

FREQUÊNCIA. A Tabela 4 mostra a frequência de entradas no centro do aparato. Uma Anova de três vias mostrou efeitos devidos ao gênero $\left(\mathrm{F}_{[1,136]}=5,003, \mathrm{P}=0,027\right)$ e ao agrupamento $\left(\mathrm{F}_{[1,136]}=15,402, \mathrm{P}<0,001\right)$, mas não ao animal presente na gaiola $\left(\mathrm{F}_{[4,136]}=\right.$ $0,653, \mathrm{P}=0,625)$, sobre a frequência de entradas no centro. Assim, os animais foram reagrupados e os dados submetidos a uma Anova de duas vias tendo como fatores gênero e agrupamento. Essa análise mostrou efeitos gerais do gênero $\left(F_{[1,152]}=5,434, P=0,021\right)$ e do agrupamento $\left(\mathrm{F}_{[1,152]}=16,094, \mathrm{P}<0,001\right)$ sobre a frequência de entradas no centro do campo aberto. Mostrou ainda que não houve interação entre os fatores $\left(\mathrm{F}_{[1,152]}=1,133, \mathrm{P}=0,289\right)$. $\mathrm{O}$ teste de comparações múltiplas indicou que as fêmeas entraram mais frequentemente que os machos no centro do campo aberto e que os animais testados em grupo entraram mais frequentemente que os testados individualmente.

TEMPO: A Tabela 4 mostra o tempo gasto no centro do campo aberto. A Anova de três vias mostrou que não ocorreram efeitos devidos ao animal presente na gaiola $\left(\mathrm{F}_{[4,136]}=1,108\right.$, $\mathrm{P}=0,355)$, ao agrupamento $\left(\mathrm{F}_{[1,136]}=0,009, \mathrm{P}=0,923\right)$ e nem ao gênero $\left(\mathrm{F}_{[1,136]}=2,863, \mathrm{P}=\right.$ 0,093) sobre o tempo gasto no centro. Além disso, mostrou que não ocorreu interação entre os fatores.

Os demais comportamentos analisados não ocorreram no centro do campo aberto. 
Tabela 4 - Comportamentos de filhotes de rato, fêmeas e machos, no centro do campo aberto na presença e na ausência de animais adultos.

Os dados representam a média individual da ocupação do centro do campo aberto e são apresentados como média \pm E. P. M. Os demais comportamentos não ocorreram no centro do campo aberto.

\begin{tabular}{|c|c|c|c|c|c|c|c|c|c|c|}
\hline \multirow[b]{3}{*}{ Comportamentos } & \multicolumn{10}{|c|}{ Animal presente na gaiola durante o teste } \\
\hline & \multicolumn{2}{|c|}{ Vazia } & \multicolumn{2}{|c|}{ Ama } & \multicolumn{2}{|c|}{ Fêmea } & \multicolumn{2}{|c|}{ Macho } & \multicolumn{2}{|c|}{ Cobaia } \\
\hline & Fêmeas & Machos & Fêmeas & Machos & Fêmeas & Machos & Fêmeas & Machos & Fêmeas & Machos \\
\hline \multicolumn{11}{|c|}{ Filhotes testados agrupados } \\
\hline Frequência & $0,60 \pm 0,09$ & $0,38 \pm 0,06$ & $0,65 \pm 0,22$ & $0,44 \pm 0,17$ & $0,60 \pm 0,14$ & $0,44 \pm 0,09$ & $0,60 \pm 0,11$ & $0,71 \pm 0,10$ & $0,75 \pm 0,21$ & $0,39 \pm 0,08$ \\
\hline Tempo (s) & $0,86 \pm 0,19$ & $0,59 \pm 0,11$ & $1,56 \pm 0,80$ & $1,03 \pm 0,44$ & $1,13 \pm 0,31$ & $0,79 \pm 0,17$ & $1,09 \pm 0,17$ & $1,31 \pm 0,28$ & $1,01 \pm 0,27$ & $0,48 \pm 0,14$ \\
\hline \multicolumn{11}{|c|}{ Filhotes testados individualmente } \\
\hline Frequência & $0,33 \pm 0,04$ & $0,40 \pm 0,11$ & $0,35 \pm 0,10$ & $0,30 \pm 0,06$ & $0,32 \pm 0,06$ & $0,35 \pm 0,06$ & $0,48 \pm 0,10$ & $0,35 \pm 0,07$ & $0,46 \pm 0,12$ & $0,25 \pm 0,04$ \\
\hline Tempo (s) & $3,52 \pm 3,06$ & $1,04 \pm 0,39$ & $0,54 \pm 0,14$ & $0,40 \pm 0,05$ & $0,40 \pm 0,07$ & $0,55 \pm 0,09$ & $0,78 \pm 0,23$ & $0,94 \pm 0,49$ & $1,10 \pm 0,47$ & $0,28 \pm 0,05$ \\
\hline
\end{tabular}




\section{DISCUSSÃO}

Vários trabalhos já mostraram que ratos preferem determinadas áreas do campo aberto em detrimento de outras (Treit, 1988; Prut et al. 2003; Ramos, 2008; Fraser, 2010; para revisões, ver: Archer, 1973; Walsh \& Cummins, 1976). De acordo com esses relatos, ratos caminham ao longo de paredes e evitam entrar na área central, bem como exibem clara preferência por permanecer em áreas com maior numero de paredes, tais como os cantos de campos abertos quadrados (Lamprea et. al. 2008; Martinez et. al. 2003). Por essa razão esse tipo de preferência não foi incluído como fator nas análises de variância. Por isso, foram analisados os efeitos de três fatores sobre as diversas medidas do comportamento dos filhotes no teste do campo aberto: presença (ou ausência) do animal adulto na gaiola, agrupamento e gênero dos filhotes.

Os resultados mostraram que a presença de um co-específico na gaiola fez com que os animais passassem mais tempo no quadrado em frente à gaiola, quando comparado às demais áreas do campo aberto. Os animais testados na presença de um co-especifico passaram mais tempo na área da gaiola do que os filhotes testados com a gaiola vazia, dedicando menos tempo aos cantos, local onde os animais passam a maior parte do tempo quando não há nenhum adulto na gaiola. Na presença da cobaia, os filhotes se aproximam no início, afastando-se em seguida para permanecerem mais tempo nas áreas mais estruturadas, como os cantos e as áreas de uma parede. O centro, independentemente da presença ou ausência do animal na gaiola foi um local muito pouco frequentado, no qual os animais quase não ficaram.

Em seus estudos, Wilson et al. (2000) supõem que a interação social com um coespecífico possa ter reduzido o estresse normalmente associado à exposição aguda ao campo aberto, confirmados a partir da diminuição dos níveis de prolactina. É possível que a presença de um co-especifico adulto possa representar para os filhotes, expostos a um ambiente aberto e aversivo, uma possível proteção.

$\mathrm{O}$ fato de os animais permanecerem por mais tempo nas áreas de duas paredes quando a gaiola estava ocupada pela cobaia, o que não aconteceu com a presença de um co-específico adulto, pode ser atribuído a uma preferência dos filhotes por um coespecífico, talvez devida à emissão de odores específicos da espécie, como relatado por Alberts e Brunjes (1978); principalmente pelo da cuidadora. Porém, em nossos estudos com os filhotes de 25 dias, a preferência de ocupação pela área da gaiola quando o macho adulto estava presente na gaiola foi maior que a preferência de ficar perto da ama-de-leite ou da fêmea, mostrando uma tendência de os animais se aproximarem mais de um macho 
do que da própria cuidadora. Hepper (1986), relatou que filhotes de ratos entre 18 e 22 dias de idade, começam a exibir uma preferência pela proximidade de um macho adulto desconhecido, porém co-específico. É importante levar em conta que estas idades coincidem com o momento em que a propensão dos machos adultos de matar os filhotes diminui significativamente, de acordo com Paul e Kupferschmidt (1975). A redução da tendência de machos adultos matarem os filhotes pode fornecer uma base de boa relação para filhotes pré-desmamados interagirem e familiarizarem-se com outros membros do grupo.

Em termos evolutivos, parece que o cuidado da parte do macho em roedores foi selecionado para ajudar a ama-de-leite a criar filhotes em situações adversas, tais como baixa temperatura ou dificuldade para obter alimento (Vieira, 2003). A presença do macho também está relacionada com a defesa dos filhotes contra possíveis predadores, o que pode ser a causa do aumento de frequência de entradas na área da gaiola pelos filhotes quando foram expostos à presença do macho. A presença do macho pode ser considerada como um estímulo que represente maior segurança para filhotes expostos a um local aberto.

Dados obtidos com outras espécies de roedores também confirmam a hipótese de que um segundo adulto pode aumentar as chances de sobrevivência dos filhotes, como no caso do hamster anão ( $P$. Campbelli) cuja presença do pai ou de um tio reduziu pela metade o tempo em que a prole ficou sozinha (Wynne-Edwards, 1995). Desta forma, diante à exposição ao campo aberto, a tendência dos animais seria buscar o local que mais lhe garantisse a sobrevivência.

As respostas dos ratos a um co-específico, a um possível predador, a um ambiente novo ou mesmo a um ambiente com estruturação diferente, podem ser influenciadas pela condição de agrupamento ou isolamento em que esses animais se encontram frente ao potencial estímulo nocivo. Os filhotes testados individualmente passaram mais tempo no quadrado em frente da gaiola do que nas demais áreas do campo aberto, ao contrário dos filhotes testados em grupo, que passaram mais tempo nos cantos e nas áreas de uma parede. Botelho (2007) sugere em seus estudos que ratos isolados ou agrupados em grande número apresentam mais ansiedade do que os agrupados em números menores quando testados no labirinto em cruz elevado. Nossos resultados corroboram o que tem sido sugerido por pesquisadores ao mostrar que os animais testados em grupo exploraram mais o campo aberto do que os animais testados isolados. Aqueles frequientaram, mesmo que por muito pouco tempo, até mesmo a área central, local mais evitado por roedores. 
Quando a cobaia estava presente na gaiola, os animais testados agrupados, aumentaram a ambulação na periferia do campo aberto (cantos e áreas de uma parede), entrando mais frequentemente nestas áreas que os animais testados com a gaiola vazia. Já aqueles testados agrupados na presença de um co-específico (ama-de-leite, fêmea ou macho), não apresentaram diferenças em relação a frequência de entradas na periferia do campo aberto quando comparados com o grupo testado sem nenhum animal na gaiola.

De acordo com Terranova (1998), para um animal, outro de outra espécie, mesmo não sendo um predador natural, também pode apresentar riscos, aumentando os níveis de ansiedade. Sugere-se, a partir de nossos resultados, que afastar-se das proximidades da cobaia possa ser um comportamento de defesa em resposta a uma suposta ameaça, mesmo que a cobaia não seja um predador natural, este é um comportamento que pode acontecer frente a um predador, ou a um co-específico, ou mesmo ao odor do animal.

Desta forma, os resultados mostraram que na presença de um co-específico, filhotes tendem a passar mais tempo na área de maior proximidade do adulto e, quando este adulto não é da mesma espécie, a tendência dos animais é de passarem mais tempo nas áreas com maior número de paredes verticais.

Quando os filhotes foram testados individualmente, a presença ou ausência de um adulto na gaiola não alterou o tempo gasto nem a frequência de entradas na periferia do campo aberto. Um experimento de Hurst et al. (1999) mostrou que ratos alojados individualmente apresentam uma tendência maior a interações sociais do que os alojados em grupo. Nos nossos experimentos, no entanto, os filhotes testados em grupo mostraram uma tendência a aproximação do adulto que não foi observado nos animais testados individualmente.

Na presença da cobaia, os filhotes testados em grupo passaram mais tempo na área de uma parede do que os testados individualmente. Já na presença de um co-específico, os filhotes testados em grupo e individualmente não apresentaram diferenças quanto ao tempo gasto nesta área. A cobaia neste caso, pode estar representando um fator de risco para os filhotes agrupados visto que, por esse critério, mostraram-se mais ansiosos quando comparados aos animais testados individualmente.

Na presença do macho ou da cobaia na gaiola, os animais testados em grupo entraram mais nas áreas periféricas do campo aberto do que os animais testados individualmente. Já na presença da ama-de-leite ou da fêmea na gaiola os animais testados agrupados não apresentaram diferenças em relação àqueles testados de forma individual. 
Os dados mostraram que, quando os filhotes tinham na gaiola o macho, a fêmea ou a cobaia, entraram mais no quadrado em frente da gaiola do que os testados com a gaiola vazia. Já com a presença da ama-de-leite, a frequência de entradas não foi diferente da dos animais controle.

Latané et al. (1971), não encontraram quaisquer diferenças em relação às medidas sociais de proximidade entre co-específicos da mesma família e de desconhecidos, da mesma forma que não encontramos diferenças de comportamento dos filhotes em frente a gaiola na presença da ama-de-leite (que teve amplo contato com os filhotes), da fêmea e do macho, esses dois últimos co-específicos desconhecidos para os animais testados.

Quando comparado o comportamento das fêmeas em relação aos machos, pôde-se observar que elas se comportaram de maneira diferente em algumas situações. As fêmeas frequentaram mais o centro e levantaram-se com mais frequência nos cantos. Em frente à gaiola, os machos limparam-se mais e passaram mais tempo se limpando que as fêmeas. Por outro lado, as fêmeas subiram na grade da gaiola com mais frequência e passaram mais tempo penduradas na grade do que os machos.

Tang et al. (2003) realizaram um experimento no qual expuseram ratos na fase neonatal a um período de 3 minutos em um ambiente novo. Posteriormente, testaram-nos aos 23 dias de idade e mostraram que os sujeitos apresentaram uma menor inibição comportamental no campo aberto, a qual foi dependente do sexo: os machos apresentaram maior atividade exploratória do que as fêmeas suas irmãs. No entanto os animais que permaneceram no ninho sem romper o vínculo familiar apresentaram resultados opostos: quando comparados entre si, as fêmeas apresentaram maior atividade no campo aberto do que os machos seus irmãos. Em nossos experimentos, as fêmeas se mostraram menos ansiosas que os machos, a julgar pelo aumento da frequiência com que elas entraram no centro do campo aberto. Esta tendência pode estar relacionada também com a idade dos animais, pois Tang et al. (2003) observaram diferença semelhante de comportamento de machos e fêmeas na mesma faixa etária em que os nossos animais foram testados. Talvez, nessa faixa etária, as fêmeas sejam menos ansiosas que os machos.

$\mathrm{O}$ animal presente na gaiola influenciou a frequência e o tempo gasto pelos filhotes levantando-se nos cantos e no quadrado em frente à gaiola. Casarrubea et al. (2009) discutem que a atividade exploratória dos animais de ficar de pé perto das paredes (levantar-se) pode representar uma atividade que visa o recolhimento de informação a partir de um ambiente desconhecido, sendo desta forma um comportamento exploratório dirigido para aquela área ou local. No entanto, esse comportamento foi observado nos 
cantos e no quadrado em frente à gaiola, não sendo estatisticamente diferente do observado na área de uma parede e nem no centro do campo aberto.

No quadrado em frente à gaiola, na presença do macho, da fêmea ou da ama, os animais levantaram-se mais, passando mais tempo levantados do que os filhotes testados com a gaiola vazia. Na presença da cobaia, a frequência de levantamentos e o tempo que eles passaram levantados em frente à gaiola não diferiram dos animais controles. Os filhotes foram mais cautelosos na busca de informações do ambiente nas proximidades da cobaia, possivelmente por desconhecerem os riscos representados por este animal, bem como as suas formas de defesa. Na Tabela 2, podemos observar uma tendência dos animais a levantarem-se mais e passarem mais tempo levantados nos cantos quando a cobaia estava presente, quando comparadas com as médias das demais situações de teste, talvez, na busca de informações do ambiente sobre a possibilidade de se afastar cada vez mais do animal desconhecido.

Os filhotes testados agrupados tiveram comportamentos diferentes dos testados individualmente em todos os demais comportamentos analisados. Os primeiros exploraram mais, farejaram mais e por mais tempo as áreas de uma parede e os cantos do que os testados individualmente, quando estava presente a cobaia ou o macho. Já na presença da ama-de-leite ou da fêmea, os filhotes testados em grupo e os testados individualmente não apresentaram diferenças em relação a esses comportamentos.

Os animais testados em grupo limparam-se mais e passaram mais tempo se limpando que os animais testados individualmente, na área de uma parede e nos cantos, passando também mais tempo levantados nos cantos.

Em relação ao comportamento de farejar, os filhotes farejaram mais e por mais tempo o quadrado defronte à gaiola quando estava presente o macho, a fêmea ou a ama-deleite, quando comparados aos testados com a gaiola vazia. Na presença da cobaia a quantidade de farejos e o tempo gasto farejando em frente a gaiola não diferiu dos animais controles.

Nos cantos, os filhotes testados individualmente com qualquer dos adultos presentes na gaiola não diferiram significativamente dos controles testados com a gaiola vazia, tanto em relação à frequência quanto ao tempo gasto farejando.

Os filhotes testados agrupados na presença da cobaia, da ama-de-leite ou da fêmea na gaiola farejaram mais e gastaram mais tempo farejando os cantos do que os animais controles. Já na presença do macho, estes não apresentaram diferenças. 
$\mathrm{Na}$ área de uma parede, os filhotes testados em grupo na presença do macho ou da cobaia passaram mais tempo farejando que os animais testados com a gaiola vazia. Nesta área, os filhotes testados individualmente com qualquer um dos adultos na gaiola não diferiram dos controles, em relação ao tempo gasto farejando, como observado também na área dos cantos.

A hipótese de Casarrubea et. al (2009) é que a relação de farejar os cantos e mergulhar a cabeça pode ter um importante significado etológico. De fato, farejar as bordas representaria o comportamento exploratório de ratos nas proximidades de um buraco, onde o animal cheira as bordas do buraco, vendo as possibilidades de explorar ou não dentro do buraco. Casarrubea et al. (2008) sugerem que o farejar estando imóvel, pode ser definido como um "padrão de seleção à espera", ou seja, um componente comportamental que representa um processo cognitivo de análise subjacente de informação sobre ambiente.

Já o comportamento de auto-limpeza é outro componente importante do repertório comportamental de roedores, constituído de diferentes padrões em um processo direcional cefalocaudal (Aldridge, et al., 2005; Kalueff, 2005). Em nossos estudos, esse comportamento foi observado em todas as áreas do campo aberto, exceto no centro. $\mathrm{Na}$ presença do macho os animais limparam-se mais que os animais testados com a gaiola vazia. Já na presença da ama-de-leite, da fêmea ou da cobaia os filhotes não apresentaram diferenças.

Spruijt et al. (1992) supunham que a auto-limpeza seria sensível às mudanças nos níveis de ansiedade dos animais, podendo ser considerada uma resposta comportamental que acompanha mudanças provocadas por estímulos ansiogênicos. A preferência de ocupação dos filhotes pela área próxima ao macho adulto pode ter aumentado a ansiedade desses animais nessa área, na qual se observou um aumento do comportamento de autolimpeza na presença do macho. No entanto, a preferência dos filhotes ainda se deu nas proximidades do macho apenas quando comparados aos testados com a gaiola vazia.

Segundo Vasquez et al. (2005), o comportamento de limpar-se pode ser organizado de forma complexa, na qual os padrões comportamentais podem mudar, dependendo da motivação e dos estímulos externos específicos. As Tabelas 1, 2 e 3 , mostram uma tendência dos animais a se limparem mais na presença da cobaia do que nas demais situações de exposição. A presença da cobaia possivelmente pode ter interferido nos níveis de ansiedade dos animais. 
Quanto ao comportamento de subir na grade da gaiola, pôde ser observado que os animais subiram mais na grade quando a ama, o macho ou a fêmea estavam presentes,em comparação aos testados com a gaiola vazia. Na presença da cobaia os filhotes não apresentaram diferenças quando comparados com o grupo controle.

O comportamento de esticar-se não foi observado para nenhuma das áreas do campo aberto.

Desta forma, pode-se concluir que a presença de um animal adulto altera a preferência de ocupação dos cantos mais estruturados por filhotes de rato em campo aberto. Quando o adulto presente é um co-especifico, a tendência dos filhotes é de se aproximar do local onde o animal se encontra (gaiola). Na presença de um animal de outra espécie, a tendência é, num primeiro momento, de aproximação e observação e, posteriormente, de permanência nos locais mais estruturados do campo aberto, como as áreas de duas paredes, o mesmo local onde ficavam os filhotes testados com a gaiola vazia. Os animais apresentaram diferenças de comportamento devidos ao agrupamento, sendo que os filhotes agrupados frequentaram mais a periferia do campo aberto e passaram mais tempo nestas áreas que os testados individualmente, que por sua vez tendem a se aproximar mais do adulto do que os testados em grupo. Aos vinte e cinco dias de vida, as fêmeas mostraram-se menos ansiosas que os machos.

De um modo geral, a principal conclusão é a de que filhotes de rato expostos a um campo aberto na presença de um adulto, exibem preferência pelas proximidades do adulto quando este é um co-específico, tendendo a permanecer nas áreas mais estruturadas quando o animal presente é de outra espécie. 


\section{REFERÊNCIAS}

Alberts; J. R., \& Brunjes, P. C. (1978). Ontogeny of thermal and olfactory determinants of huddling in the rat. Journal Comparative Physiology Psychology, 92 (5), 897-906.

Aldridge, J.W. (2005). Grooming. In.: WHISHAW, I. Q., \& KOLB, B. (eds). The behavior of the laboratory rat: a handbook with tests. _: Oxford University Press US, 141-149.

Archer, J. (1975). Rodent sex differences in emotional and related behavior. Behavioral Biology, 14 (4), 451-479.

Archer, J. (1973). Tests for emotionality in rats and mice: a review. Animal Behaviour, 21 (2), 205235.

Asano, Y. (1986). Characteristics of open field behavior of Wistar and Sprague-Dawley rats. Jikken Dobutsu. Experimental Animals, 35 (4), 505-508.

Bakshi, V. P., \& Kalin, N. H. (2002). Animal models and endophenotypes of anxiety and stress disorders. In.: Davis, K.L.; Charney, D.; Coyle, J.T. \& Nemeroff, C.( eds). Neuropsychopharmacology: the 5th generation of progress, 883-900.

Barnett, S. A. (1967). A Study In Behaviour: Principles Of Ethology And Behavioural Physiology Displayed Mainly In The Rat. _: Methuen.

Barnett, S. (1975). The Rat: A Study in Behavior. Chicago: University of Chicago Press.

Beijamini, V., \& Guimarães, F. S. (2006). c-Fos expression increase in NADPH-diaphorase positive neurons after exposure to a live cat. Behavioural Brain Research, 170 (1), 52-61.

Berlyne, D. E. (1960). Conflict, arousal, and curiosity. New York: Mc Graw-Hill Book Company, $350 \mathrm{p}$.

Biondi, M., \& Picardi, A. (1999). Psychological stress and neuroendocrine function in humans: the last two decades of research. Psychotherapy and Psychosomatics, 68 (3), 114-150.

Blanchard, D. C., \& Blanchard, R. J. (1984). Affect and aggression: An animal model applied to human behavior. Advances in the study of aggression, 1, 1-62.

Blanchard, D. C., \& Blanchard, R. J. (1988). Ethoexperimental approaches to the biology of emotion. Annual Review of Psychology, 39, 43-68.

Blanchard, D. C., Li, C.I., Hubbard, D., Markham, C. M., Yang, M., Takahashi, L. K., Blanchard, R. J. (2003). Dorsal premammillary nucleus differentially modulates defensive behaviors induced by different threat stimuli in rats. Neuroscience Letters 345 (3), 145-148.

Blanchard, R. J., \& Blanchard, D. C. (1984). Advances in the Study of Aggression, Volume 1. Academic Press.

Blanchard, R. J., \& Blanchard, D. C. (1989). Antipredator defensive behaviors in a visible burrow system. Journal of Comparative Psychology (Washington, D.C.: 1983), 103 (1), 70-82.

Blanchard, R. J., \& Blanchard, D. C. (1971). Defensive reactions in the albino rat. Learning and Motivation, 2 (4), 351-362. 
Blanchard, R. J., \& Blanchard, D. C. (1972). Effects of hippocampal lesions on the rat's reaction to a cat. Journal of Comparative and Physiological Psychology, 78 (1), 77-82.

Blanchard, R. J.; Yang, M.; Li, C. I.; Gervacio, A., \& Blanchard, D. C. (2001). Cue and context conditioning of defensive behaviors to cat odor stimuli. Neuroscience and Biobehavioral Reviews, 25 (7-8), 587-595.

Botelho, S.; Estanislau, C., \& Morato, S. (2007). Effects of under- and overcrowding on exploratory behavior in the elevated plus-maze. Behavioural Processes, 74 (3), 357-362.

Butler, R. A. (1953). Discrimination learning by rhesus monkeys to visual-exploration motivation. Journal of Comparative and Physiological Psychology, 46 (2), 95-98.

Campos-De-Carvalho, M. I., \& Mingorance, R. C. (1999). Zonas circunscritas e ocupação do espaço por crianças pequenas em creche. Revista Interamericana de Psicologia, 33 (2), 67-89.

Campos-De-Carvalho, M. I., \& Rossetti-Ferreira, M. C. (1993). Importance of Spatial Arrangements for Young Children in Day Care Centres. CHILDRENS ENVIRONMENTS, $10(1), 19-30$.

Canteras, N. S.; Chiavegatto, S.; Ribeiro Do Valle, L. E., \& Swanson, L. W. (1997). Severe reduction of rat defensive behavior to a predator by discrete hypothalamic chemical lesions. Brain Research Bulletin, 44 (3), 297-305.

Canteras, N. S., \& Goto, M. (1999). Fos-like immunoreactivity in the periaqueductal gray of rats exposed to a natural predator. Neuroreport, 10 (2), 413-418.

Carvalho, A. M. (1997). O desenvolvimento social da criança e seus contextos de emergência. Temas em Psicologia, 3, 27-31.

Casarrubea, M.; Sorbera, F., \& Crescimanno, G. (2008). Multivariate analysis of the modifications induced by an environmental acoustic cue on rat exploratory behavior. Physiology \& Behavior, 93 (4-5), 687-696.

Casarrubea, M.; Sorbera, F., \& Crescimanno, G. (2009). Structure of rat behavior in hole-board: I) multivariate analysis of response to anxiety. Physiology \& Behavior, 96 (1), 174-179.

Cirulli, F.; Terranova, M. L., \& Laviola, G. (1996). Affiliation in periadolescent rats: behavioral and corticosterone response to social reunion with familiar or unfamiliar partners. Pharmacology, Biochemistry, and Behavior, 54 (1), 99-105.

Critchlow, V.; Liebelt, R. A.; Bar-Sela, M.; Mountcastle, W., \& Lipscomb, H. S. (1963). Sex difference in resting pituitary-adrenal function in the rat. American Journal of Physiology, $205(5), 807-815$.

Crusio, W. E.; Schwegler, H., \& Van Abeelen, J. H. (1989). Behavioral responses to novelty and structural variation of the hippocampus in mice. I. Quantitative-genetic analysis of behavior in the open-field. Behavioural Brain Research, 32 (1), 75-80. 
Cruz, A. P.; Frei, F., \& Graeff, F. G. (1994). Ethopharmacological analysis of rat behavior on the elevated plus-maze. Pharmacology, Biochemistry, and Behavior, 49 (1), 171-176.

Dielenberg, R. A.; Hunt, G. E., \& Mcgregor, I. S. (2001). "When a rat smells a cat": the distribution of Fos immunoreactivity in rat brain following exposure to a predatory odor. Neuroscience, 104 (4), 1085-1097.

Felson, R. B. (1983). Aggression and violence between siblings. Social Psychology Quarterly, 46 (4), 271-285.

File, S. E. (1990). Interactions of anxiolytic and antidepressant drugs with hormones of the hypothalamic-pituitary-adrenal axis. Pharmacology \& therapeutics, 46 (3), 357-375.

Fraser, L. M.; Brown, R. E.; Hussin, A.; et al. (2010). Measuring anxiety- and locomotion-related behaviours in mice: a new way of using old tests. Psychopharmacology.

Gambardella, P.; Greco, A. M.; Sticchi, R.; Bellotti, R., \& Di Renzo, G. (1994). Individual housing modulates daily rhythms of hypothalamic catecholaminergic system and circulating hormones in adult male rats. Chronobiology International, 11 (4), 213-221.

Genaro, G., \& Schmidek, W. R. (2002). The influence of handling and isolation postweaning on open field, exploratory and maternal behavior of female rats. Physiology \& Behavior, 75 (5), 681-688

Grossen, N. E., \& Kelley, M. J. (1972). Species-specific behavior and acquisition of avoidance behavior in rats. Journal of Comparative and Physiological Psychology, 81 (2), 307-310.

Guillet, R., \& Kellogg, C. K. (1988). Age-related effects of handling, diazepam exposure, and gonadectomy on corticosterone response to stress in the rat. In: Society Neuroscience Abstracts. Anais, 14, 112-115.

Hall, C. S. (1934). Emotional behavior in the rat: I. Defecation and urination as measures of individual differences in emotionality. Journal of Comparative Psychology, 18, 385-403.

Hennessy, M. B. (1986). Effects of social partners on pituitary-adrenal activity during novelty exposure in adult female squirrel monkeys. Physiology \& Behavior, 38 (6), 803-807.

Hepper, P. G. (1986). Kin recognition: functions and mechanisms. A review. Biological Reviews Cambridge Philos Society, 61 (1), 63-93.

Hurst; Barnard; Tolladay; Nevision, \& West. (1999). Housing and welfare in laboratory rats: effects of cage stocking density and behavioural predictors of welfare. Animal Behaviour, 58 (3), 563-586.

Johnston, A. L., \& File, S. E. (1991). Sex differences in animal tests of anxiety. Physiology \& Behavior, 49 (2), 245-250.

Kalueff, A. V., \& Tuohimaa, P. (2005). The grooming analysis algorithm discriminates between different levels of anxiety in rats: potential utility for neurobehavioural stress research. Journal of Neuroscience Methods, 143 (2), 169-177. 
Kandel, E. (1976). Cellular basis of behavior: An introduction to invertebrate neurobiology. San Francisco: Freeman.

Kirschbaum, C.; Klauer, T.; Filipp, S. H., \& Hellhammer, D. H. (1995). Sex-specific effects of social support on cortisol and subjective responses to acute psychological stress. Psychosomatic Medicine, 57 (1), 23-31.

Kitay, J. I. (1961). Sex differences in adrenal cortical secretion in the rat. Endocrinology, 68, 818824.

Lamprea, M. R.; Cardenas, F. P.; Setem, J., \& Morato, S. (2008). Thigmotactic responses in an open-field. Brazilian Journal of Medical and Biological Research. Revista Brasileira de Pesquisas Médicas e Biológicas / Sociedade Brasileira de Biofísica, 41 (2), 135-140.

Latané, B.; Schneider, E.; Waring, P., \& Zweigenhaft, R. (1971). The specificity of social attraction in rats. Psychonomic Science, 23 (1A), 28-29.

Martinez, R. C. R. (2003). Efeitos da estruturação espacial do campo aberto no comportamento exploratório de ratos adultos e filhotes. Dissertação de mestrado. Universidade de São Paulo.

Mineka, S.; Keir, R., \& Price, V. (1980). Fear of snakes in wild-and lab-reared rhesus monkeys. Animal Learning and Behavior, 8, 653-663.

Paul, L.; \& Kupferschmidt, J. (1975). Killing of conspecific and mouse young by male rats. Journal of Comparative and Physiological Psychology, 88, 755-763.

Poltyrev, T.; Keshet, G. I.; Kay, G., \& Weinstock, M. (1996). Role of experimental conditions in determining differences in exploratory behavior of prenatally stressed rats. Developmental Psychobiology, 29 (5), 453-462.

Prut, L., \& Belzung, C. (2003). The open field as a paradigm to measure the effects of drugs on anxiety-like behaviors: a review. European Journal of Pharmacology, 463 (1-3), 3-33.

Ramos, A. (2002). Animal models of anxiety: do I need multiple tests? Trends in Pharmacological Sciences, 29 (10), 493-498.

Rebouças, R. C., \& Schmidek, W. R. (1997). Handling and isolation in three strains of rats affect open field, exploration, hoarding and predation. Physiology \& Behavior, 62 (5), 11591164.

Rex, A.; Sondern, U.; Voigt, J. P.; Franck, S., \& Fink, H. (1996). Strain differences in fearmotivated behavior of rats. Pharmacology, Biochemistry and Behavior, 54 (1), 107-111.

Ross, S. R., \& Lukas, K. E. (2006). Use of space in a non-naturalistic environment by chimpanzees (Pan troglodytes) and lowland gorillas (Gorilla gorilla gorilla). Applied Animal Behaviour Science, 96 (1-2), 143-152.

Ross, S. R.; Schapiro, S. J.; Hau, J., \& Lukas, K. E. (2009). Space use as an indicator of enclosure appropriateness: A novel measure of captive animal welfare. Applied Animal Behaviour Science, 121 (1), 42-50. 
Russell, P. A. (1977). Sex differences in rats' stationary exploration as a function of stimulus and environmental novelty. Animals Learning and Behavior, 5, 297-302.

Schmitt, U., \& Hiemke, C. (1998). Strain differences in open-field and elevated plus-maze behavior of rats without and with pretest handling. Pharmacology, Biochemistry, and Behavior, 54, 355-361.

Shors, T. J., \& Wood, G. E. (1995). Contribution of stress and gender to exploratory preferences for familiar versus unfamiliar conspecifics. Physiology \& behavior, 58 (5), 995-1002.

Simon, P.; Dupuis, R., \& Costentin, J. (1994). Thigmotaxis as an index of anxiety in mice. Influence of dopaminergic transmissions. Behavioural Brain Research, 61 (1), 59-64.

Smith, L. K.; Forgie, M. L., \& Pellis, S. M. (1998). Mechanisms underlying the absence of the pubertal shift in the playful defense of female rats. Developmental Psychobiology, 33 (2), $147-156$.

Spruijt, B. M.; Van Hooff, J. A., \& Gispen, W. H. (1992). Ethology and neurobiology of grooming behavior. Physiological Reviews, 72 (3), 825-852.

Stambak, M., \& Verba, M. (1986). Organization of social play among toddlers: An ecological approach. In.: Mueller, E. C. \& Cooper, C. R. (Orgs.). Process and outcome in peer relationships. Orlando, Flórida: Academic Press, 253-295.

Stanton, M. E.; Patterson, J. M., \& Levine, S. (1985). Social influences on conditioned cortisol secretion in the squirrel monkey. Psychoneuroendocrinology, 10 (2), 125-134.

Tang, A. C.; Nakazawa, M., \& Reeb, B.C. (2007). Neonatal novelty exposure affects sex difference in open field disinhibition. Neuroreport. 26; 14 (12), 1553-1556.

Terranova, M. L.; Cirulli, F., \& Laviola, G. (1999). Behavioral and hormonal effects of partner familiarity in periadolescent rat pairs upon novelty exposure. Psychoneuroendocrinology, 24 (6), 639-656.

Terranova, M. L.; Laviola, G., \& Alleva, E. (1993). Ontogeny of amicable social behavior in the mouse: gender differences and ongoing isolation outcomes. Developmental Psychobiology, $26(8), 467-481$.

Terranova, M. L.; Laviola, G.; De Acetis, L., \& Alleva, E. (1998). A description of the ontogeny of mouse agonistic behavior. Journal of Comparative Psychology (Washington, D.C.: 1983), $112(1), 3-12$.

Thorsteinsson, E. B.; James, J. E., \& Gregg, M. E. (1998). Effects of video-relayed social support on hemodynamic reactivity and salivary cortisol during laboratory-based behavioral challenge. Health Psychology: Official Journal of the Division of Health Psychology, American Psychological Association, 17 (5), 436-444.

Traylor-Holzer, K., \& Fritz, P. (2005). Utilization of space by adult and juvenile groups of captive chimpanzees (Pan troglodytes). Zoo biology, 4 (2), 115-127. 
Treit, D. (1985). Animal models for the study of anti-anxiety agents: a review. Neuroscience and Biobehavioral Reviews, 9 (2), 203-222.

Treit, D., \& Fundytus, M. (1988). Thigmotaxis as a test for anxiolytic activity in rats. Pharmacology, Biochemistry, and Behavior, 31 (4), 959-962.

Van Der Staay, F. J. (2006). Animal models of behavioral dysfunctions: basic concepts and classifications, and an evaluation strategy. Brain Research Reviews, 52 (1), 131-159.

Vasquez, L.H., Vasquez, R.H., \& Chapin, J.K. (2005). Somatosensation. In.: Whishaw, I. Q., \& Kolb, B. (eds). The behavior of the laboratory rat: a handbook with tests. Oxford University Press US, 60-68.

Vieira, M. L., \& Brown, R. (2003). Efects of the presence of the father and parental experience on pup development in California mice (Peromyscus californicus). Developmental Psychobiology, 42, 246-251.

Vogt, J. L.; Coe, C. L., \& Levine, S. (1981). Behavioral and adrenocorticoid responsiveness of squirrel monkeys to a live snake: is flight necessarily stressful? Behavioral and Neural Biology, 32 (4), 391-405.

Wall, P. M. \& Messier, C. (2001). Methodological and conceptual issues in the use of the elevated pluz-maze as a psychological measurement instrument of animal anxiety-like behavior. Neuroscience Biobehavior Review, 25 (3), 275-86.

Walsh, R. N., \& Cummins, R. A. (1976). The Open-Field Test: a critical review. Psychological Bulletin, 83 (3), 482-504.

Whimbey, A. E., \& Denenberg, V. H. (1967). Two independent behavioral dimensions in openfield performance. Journal of Comparative and Physiological Psychology, 63 (3), 500-504.

Wilson, E. O. (1975). Sociobiology: the new synthesis Cambridge. MA: Harvard.

Wilson, J. H.; Mckinley, S. A., \& Young, B. L. (2000). Prolactin levels in juvenile and adult rats following acute restraint and the open field. Physiology \& Behavior, 68 (3), 383-387.

Wynne-Edwards, K.E. (1995). Biparental care in Djungarian but not Siberian dwarf hamsters (Phodopus) . Animal Behaviour. 50, 1571-1585. 